\title{
Interleukin-1 $\beta$ Induces Hyaluronan and CD44-Dependent Cell Protrusions That Facilitate Fibroblast-Monocyte Binding
}

\author{
Soma Meran, John Martin, Dong Dong Luo, Robert Steadman, and Aled Phillips
}

From the Institute of Nephrology, Cardiff University, University Hospital of Wales, Heath Park, Cardiff, United Kingdom

\author{
Accepted for publication \\ February 11, 2013. \\ Address correspondence to \\ Soma Meran, MBChB, Ph.D., \\ MRCP, Institute of Nephrology, \\ University Hospital of Wales, \\ Heath Park, Cardiff, UK CF14 \\ 4XN. E-mail: merans@cf.ac.uk.
}

\begin{abstract}
Persistent inflammation is a well-known determinant of progressive tissue fibrosis; however, the mechanisms underlying this process remain unclear. There is growing evidence indicating a role of the cytokine IL-1 $\beta$ in profibrotic responses. We previously demonstrated that fibroblasts stimulated with IL-1 $\beta$ increased their generation of the polysaccharide hyaluronan $(\mathrm{HA})$ and increased their expression of the HA synthase enzyme (HAS-2). The aim of this study was to determine the significance of IL-1 $\beta-$ induced changes in HA and HAS-2 generation. In this study, we found that stimulation of fibroblasts with $\mathrm{IL}-1 \beta$ results in the relocalization of $\mathrm{HA}$ associated with the cell to the outer cell membrane, where it forms HAS2- and CD44-dependent cell membrane protrusions. CD44 is concentrated within the membrane protrusions, where it co-localizes with the intracellular adhesion molecule 1 . Furthermore, we have identified that these cell protrusions enhance IL-1 $\beta$-dependent fibroblast-monocyte binding through MAPK/ERK signaling. Although previous data have indicated the importance of the HA-binding protein TSG- 6 in maintaining the transforming growth factor $\beta 1$-dependent HA coat, TSG- 6 was not essential for the formation of the IL-1 $\beta$-dependent HA protrusions, thus identifying it as a key difference between IL$1 \beta$ - and transforming growth factor $\beta 1$-dependent HA matrices. In summary, these data suggest that IL-1 $\beta$-dependent HA generation plays a role in fibroblast immune activation, leading to sequestration of monocytes within inflamed tissue and providing a possible mechanism for perpetual inflammation. (Am J Pathol 2013, 182: 2223-2240; http://dx.doi.org/10.1016/j.ajpath.2013.02.038)
\end{abstract}

Fibrosis is a pathological process that underlies a multitude of organ-specific diseases in the lung, liver, and kidneys, leading to a wide variety of clinical disorders. ${ }^{1-4}$ It is characterized by the accumulation of extracellular matrix and by the persistence of myofibroblasts in affected tissues and is causally linked to increased circulating levels of the cytokine transforming growth factor (TGF)- $\beta 1 .^{5-8}$ Persistent inflammation after mechanical, microbial, or physiologic tissue injury is a well-known determinant of progressive fibrosis; however, the mechanistic processes underlying this are poorly understood.

Persistent inflammation leads to a progressive shift in the type of cells present at the site of injury. As inflammation progresses, the presence of macrophages become dominant in the injured tissue. ${ }^{9-11}$ In addition, an abnormal expansion and phenotypic activation of the fibroblastic cell population becomes more apparent as fibrous tissue is progressively laid down. ${ }^{8,12}$ Previous evidence suggests that complex interactions between fibroblasts and monocytes/macrophages play an important role in the progression of fibrous disease. ${ }^{13-15}$ Hence, monocytes and fibroblasts are considered to be key players in fibrogenesis. In addition, a variety of cytokines and growth factors have been demonstrated to be present at sites of chronic inflammation and active fibrosis. Of these, TGF- $\beta 1$ is largely recognized as the most important profibrotic cytokine in terms of direct stimulation of fibroblast activation and matrix generation, which typifies fibrosis. ${ }^{16-19}$ However, there is accumulating evidence to indicate that a variety of other proinflammatory cytokines can also promote fibrogenesis, either through enhancing the profibrotic actions of TGF- $\beta 1$ or through direct profibrotic effects on cells. A growing body of evidence indicates a pivotal role for the

Supported by Kidney Research UK Interdepartmental Funding. 
inflammatory cytokine IL-1 $\beta$ in profibrotic responses. ${ }^{20-22}$ In vitro studies have demonstrated that it can exert a variety of profibrotic effects on a range of cell types, including stimulation of proliferation and extracellular matrix production; induction of stimuli, such as TGF- $\beta 1$, nitric oxide, and reactive oxygen species; and induction of adhesion molecule expression. ${ }^{23-32}$ We have previously reported that IL- $1 \beta$ can enhance TGF- $\beta 1$ signaling. ${ }^{33}$ Moreover, several studies in humans and animals have reported that IL-1 $\beta$ staining is strongly associated with fibrotic lesions in liver disease, in parenchymal lung disorders, and with the severity of tubulointerstitial lesions and proteinuria in the kidney. ${ }^{24,34-36}$

Hyaluronan (HA) is a ubiquitous connective tissue polysaccharide known for its role in maintaining matrix stability. It is synthesized by HA synthase (HAS) enzymes of which three vertebrate genes have been isolated and characterized: HASl, $H A S 2$, and $H A S 3 .{ }^{37,38}$ In addition to its homeostatic functions, it also has a role in regulating cell functions through interaction with cell-surface receptors (principally CD44 and RHAMM); hence, it plays a recognized role in mediating cell-cell adhesion, migration, proliferation, and differentiation. ${ }^{39-44}$ As a result, it is an important regulator of tissue remodeling and has been implicated in a number of biological and pathological processes, including wound healing, embryonic development, tumor growth, and now fibrosis. ${ }^{45-52}$ In our attempts to delineate the cell biology of fibrosis, our research has previously focused on the phenotypic activation of fibroblasts by TGF- $\beta 1$. This earlier work demonstrated that phenotypic activation of fibroblasts to myofibroblasts, characterized by increased $\alpha$-smooth muscle actin ( $\alpha$-SMA) expression, was dependent on TGF- $\beta 1$ and was mediated by HA. ${ }^{49}$ Specifically, we demonstrated that stimulation of fibroblasts with TGF$\beta 1$-induced HAS enzyme expression and HA synthesis and resulted in the formation of HA-dependent pericellular matrices (HA coats). The assembled HA coats were subsequently found to function in mediating TGF- $\beta 1$-driven phenotypic differentiation in fibroblasts. We also have previous data demonstrating that, similar to TGF- $\beta 1$, stimulation of fibroblasts with IL-1 $\beta$ also induces HAS enzyme expression and HA synthesis and leads to the formation of HA pericellular matrices. ${ }^{49,51}$ However, in contrast to the TGF- $\beta 1$-induced coats, the IL- $1 \beta$-induced HA coats were not clearly related to a profibrotic phenotype. The functional significance of IL-1 $\beta$ induced HA changes are therefore unclear.

In this article, we study the functional effects of IL-1 $\beta-$ induced HA in the fibroblast. We report that stimulation of fibroblasts with IL- $1 \beta$ results in a HA pericellular coat that is distinct from the HA coat assembled after TGF- $\beta 1$. IL- $1 \beta$ induces the fibroblast cell membranes to form multiple spiculated protrusions from which cell-associated HA projects in a linear manner. CD44 is critical to the formation of these cell structures and is redistributed to be concentrated within the membrane spicules, where it co-localizes with intercellular adhesion molecule (ICAM)-1. Functionally, these HA-rich structures appear to enhance ICAM-1 and monocyte interactions and promote fibroblast-monocyte binding.

\section{Materials and Methods}

\section{Materials}

All reagents were purchased from Sigma (St. Louis, MO) or Invitrogen unless otherwise stated. Reverse transcription reagents, siRNA transfection reagents, and quantitative PCR (qPCR) primers and reagents were purchased from Invitrogen (Paisley, UK) and Applied Biosystems (Cheshire, UK). Radioisotopes were purchased from Amersham Pharmacia Biotech (Little Chalfont, Bucks, UK), and the ERK (MEK) inhibitor was purchased from Calbiochem (Nottingham, UK).

\section{Cell Culture}

Human lung fibroblasts (AG02262) were purchased from Coriell Cell Repositories (Coriell Institute for Medical Research, Camden, NJ). The cells were cultured in Dulbecco's modified Eagle's medium (DMEM)/F12 containing $2 \mathrm{mmol} / \mathrm{L}$ L-glutamine, $100 \mathrm{U} / \mathrm{mL}$ of penicillin, and $100 \mu \mathrm{g} / \mathrm{mL}$ of streptomycin supplemented with $10 \%$ fetal bovine serum (Biological Industries Ltd., Cumbernauld, UK). The cells were maintained at $37^{\circ} \mathrm{C}$ in a humidified incubator in an atmosphere of $5 \% \mathrm{CO}_{2}$, and fresh growth medium was added to the cells every 3 to 4 days until the cells were ready for experimentation. The cells were incubated in serum-free medium for 48 hours before use in all experiments, and all experiments were performed under serum-free conditions unless otherwise stated. All experiments were undertaken using cells at passage 6 to 10 .

\section{Analysis of ${ }^{3} \mathrm{H}$-Radiolabeled $\mathrm{HA}$}

Cells were grown to full confluence in T75 flasks. They were then growth arrested in serum-free medium for 48 hours. After this they were incubated with either serum-free medium containing $20 \mu \mathrm{Ci} / \mathrm{mL}$ of ${ }^{3} \mathrm{H}$-glucosamine for 24 hours or serumfree medium containing $20 \mu \mathrm{Ci} / \mathrm{mL}{ }^{3}{ }^{3} \mathrm{H}$-glucosamine together with $1 \mathrm{ng} / \mathrm{mL}$ of recombinant human IL-1 $\beta$ (R\&D Systems, Abingdon, UK) for 24 hours. The culture medium was then removed and the cell washed with PBS. The wash and medium were combined to form the conditioned medium extract. This extract was then treated with an equal volume of $200 \mu \mathrm{g} / \mathrm{mL}$ of Pronase in $100 \mathrm{mmol} / \mathrm{L}$ Tris-HCL, $\mathrm{pH} \mathrm{8,} \mathrm{0.05 \%} \mathrm{sodium} \mathrm{azide}$ for 24 hours. The samples were then passed over DEAESephacel ion exchange columns equilibrated with $8 \mathrm{~mol} / \mathrm{L}$ urea in $20 \mathrm{mmol} / \mathrm{L}$ of BisTris buffer, $\mathrm{pH} 6$, containing $0.2 \%$ Triton X100 to remove any low-molecular-weight peptides and unincorporated radiolabel. HA was eluted in $8 \mathrm{~mol} / \mathrm{L}$ urea buffer containing $0.3 \mathrm{~mol} / \mathrm{L} \mathrm{NaCl}$. Each sample was split into two, and the HA was precipitated with three volumes of $1 \%$ potassium acetate in $95 \%$ ethanol in the presence of $50 \mu \mathrm{g} / \mathrm{mL}$ of each HA, heparin, and chondroitin sulfate as co-precipitants. The first half of each sample was resuspended in $500 \mu \mathrm{L}$ of $4 \mathrm{~mol} / \mathrm{L}$ guanidine buffer and analyzed on a Sephacryl S-500 column equilibrated with $4 \mathrm{~mol} / \mathrm{L}$ guanidine buffer. To confirm that the chromatography profile generated was the result of radiolabeled HA, 
the second half of each sample was digested at $37^{\circ} \mathrm{C}$ overnight with $1 \mathrm{U}$ of Streptomyces hyalurolyticus hyaluronidase (ICN Pharmaceuticals Ltd., Basingstoke, UK) in $200 \mu \mathrm{L}$ of 20 $\mathrm{mmol} / \mathrm{L}$ sodium acetate, $\mathrm{pH} 6$, containing $0.05 \%$ sodium azide and $0.15 \mathrm{~mol} / \mathrm{L}$ sodium chloride. The sample was then mixed with an equal volume of $4 \mathrm{~mol} / \mathrm{L}$ guanidine buffer and analyzed on the same Sephacryl S-500 column equilibrated with $4 \mathrm{~mol} / \mathrm{L}$ guanidine buffer. To produce the chromatography profile, the ${ }^{3} \mathrm{H}$ activity for each half of the sample was normalized and corrected for dilution, and then the $S$. hyalurolyticus hyaluronidase-resistant counts were subtracted. The chromatography profiles only depict $S$. hyalurolyticus hyaluronidase-sensitive activity in each fraction plotted against fraction number. The column was calibrated with ${ }^{3} \mathrm{H}$-glucosamine hydrochloride, $\mathrm{M}_{\mathrm{r}}$ $215 ;{ }^{35}$ S-chondroitin sulfate glycosaminoglycans, $\mathrm{M}_{\mathrm{r}} 25 \times 10^{3}$; decorin, $\mathrm{M}_{\mathrm{r}} 10 \times 10^{4}$; and ${ }^{35}$ S-versican, $\mathrm{M}_{\mathrm{r}} 1.3 \times 10^{6}$.

\section{RT-PCR and $q P C R$}

RT-PCR and qPCR was used to assess HAS2, ICAM-1, CD45, TSG-6, and CD44 standard isoform (product code: Hs01075861_m1) mRNA expression. Primers and probes for these genes were commercially designed and purchased from Applied Biosystems. The cells were grown in 35-mm dishes and washed with PBS before lysis with Tri-reagent and RNA purification according to the manufacturer protocol. Reverse transcription was performed using the High Capacity cDNA Reverse Transcription Kit according to the manufacturer protocol (Applied Biosystems). This kit uses the random primer method for initiating cDNA synthesis. As a negative control reverse transcription was performed with sterile $\mathrm{H}_{2} \mathrm{O}$ replacing the RNA sample. We performed qPCR using the 7900HT fast real-time PCR system from Applied Biosystems. PCR was performed in a final volume of $20 \mu \mathrm{L}$ per sample as follows: $1 \mu \mathrm{L}$ of reverse transcription product, $1 \mu \mathrm{L}$ of target gene primers and probe, $10 \mu \mathrm{L}$ of Taqman Universal PCR mastermix, and $8 \mu \mathrm{L}$ of sterile water. Amplification was performed using a cycle of $95^{\circ} \mathrm{C}$ for 1 second and $60^{\circ} \mathrm{C}$ for 20 seconds for 40 cycles. As a negative control, PCR was performed with sterile $\mathrm{H}_{2} \mathrm{O}$ replacing the cDNA sample. PCR was simultaneously performed for ribosomal RNA (primers and probe commercially designed and purchased from Applied Biosystems) as a standard reference gene. The comparative CT method was used for relative quantification of gene expression. The CT (threshold cycle where amplification is in the linear range of the amplification curve) for the standard reference gene (ribosomal RNA) was subtracted from the target gene CT to obtain the $\Delta \mathrm{CT}$. The mean $\Delta \mathrm{CT}$ values for replicate samples were then calculated. The expression of the target gene in experimental samples relative to expression in control samples was then calculated using the equation:

$$
2^{-[\Delta \mathrm{CT}(1)-\Delta \mathrm{CT}(2)]}
$$

where $\Delta \mathrm{CT}(1)$ is the mean $\Delta \mathrm{CT}$ calculated for the experimental samples, and $\Delta \mathrm{CT}(2)$ is the mean $\Delta \mathrm{CT}$ calculated for the control samples.

\section{siRNA Transfection}

Transient transfection of fibroblasts was performed with specific siRNA nucleotides (Applied Biosystems) targeting HAS2, CD44, or TSG-6. Transfection was performed using Lipofectamine 2000 transfection reagent (Invitrogen) in accordance with the manufacturer protocol. Briefly, cells were grown to $70 \%$ confluence in antibiotic free medium in either 35-mm dishes or 8-well Permanox chamber slides. Five microliters of the transfection reagent was diluted in $250 \mu \mathrm{L}$ of Opti-MEM reduced growth medium (GIBCO, Paisley, UK) and left to incubate for 5 minutes at room temperature. The specific siRNA oligonucleotides were diluted in Opti-MEM reduced growth medium to achieve a final concentration of $30 \mathrm{~nm}$. The transfection agent and siRNA mixtures were then combined and incubated at room temperature for an additional 20 minutes. The newly formed transfection complexes were subsequently added to the cells and incubated at $37^{\circ} \mathrm{C}$ with $5 \% \mathrm{CO}_{2}$ for 24 hours in serumfree medium before experimentation. As a control, cells were transfected with negative control siRNA (a scrambled sequence that bears no homology to the human genome) (Applied Biosystems).

\section{Immunocytochemistry}

Cells were grown to $70 \%$ confluence in eight-well Permanox chamber slides. The culture medium was removed and the cells washed with sterile PBS before fixation in acetone-methanol $(1: 1 \mathrm{v} / \mathrm{v})$ for 5 minutes at room temperature. After fixation, slides were blocked with 5\% bovine serum albumin for 20 minutes before a further washing step with PBS. Subsequently, the slides were incubated with the primary antibody diluted in $0.1 \%$ bovine serum albumin and PBS for 2 hours at room temperature. After a further washing step, slides were incubated with fluorescein isothiocyanate (FITC)-conjugated and/or tetramethyl rhodamine isothiocyanate-conjugated secondary antibodies for 1 hour at room temperature (Dako, Cambridgeshire, UK). Cell nuclei were enhanced by staining with DAPI. Cells were then mounted and analyzed by confocal fluorescent microscopy.

In some experiments, U937 cells in co-culture with fibroblasts were assessed. This is a monocyte cell line originally derived from a human histiocytic lymphoma purchased from the ATCC (Manassas, VA). Their use to study monocyte behavior has been well established previously. ${ }^{53}$ They were grown in suspension culture in RPMI medium supplemented with L-glutamine and penicillin/streptomycin and containing $5 \%$ fetal bovine serum until an appropriate cell density was achieved $\left(1 \times 10^{6}\right.$ cells $\left./ \mathrm{mL}\right)$. They were then incubated for specified number of hours with fibroblasts grown to $70 \%$ confluence under specific experimental conditions (details are outlined in the figure legends). The cultures were then washed 10 times with $1000 \mu \mathrm{L}$ of PBS to remove any unbound U937 cells. Subsequently, the cells were fixed with 1:1 acetone: methanol for 5 minutes at room temperature and blocked and 
treated with primary and secondary antibodies as described. Cell nuclei were enhanced by staining with DAPI, thereby facilitating localization of monocytes.

The following primary antibodies were used: rat anti-human CD44 antibody (Calbiochem A020), biotinylated hyaluronic acid binding protein (bHABP) (Seikagaku Corporation, Tokyo, Japan), mouse anti-human ICAM-1 antibody (R\&D Systems, Abingdon, UK), rat anti-CD44 FITC conjugate (Abcam), and cholera toxin subunit B (CtxB) Alexa Fluor 594 conjugate (Molecular Probes, Paisley, UK, and Invitrogen). The following secondary antibodies were used: rabbit anti-rat tetramethyl rhodamine isothiocyanate, goat anti-mouse FITC (Dakocytomation, Cambridgeshire, YK), and Avidin-FITC (Vector Laboratories, Burlingame, CA).

\section{Immunoblotting and Western Analysis}

Western blot analysis was used to assess expression of phosphorylated ERK1 and ERK2 (p44/42), phosphorylated P38, and TSG-6. Cells were grown to confluence in 35-mm dishes, and Western blot analysis was performed as described in our previous articles. ${ }^{50}$ A $5.3-\mu \mathrm{g} / \mathrm{mL}$ rabbit monoclonal antibody against human TSG-6 primary antibodies (donated from Dr. Anthony Day), monoclonal rabbit antiphosphorylated p44/42-mitogen activated protein kinase antibody for ERK1 and ERK2 (dilution 1:1000), and monoclonal rabbit antiphosphorylated P38-mitogen activated protein kinase antibody (dilution 1:500) from Cell Signaling Technology (Beverly, MA) were used. Expression of glyceraldehyde-3-phosphate dehydrogenase (GAPDH) was analyzed as a control to ensure equal loading (anti-GAPDH, 1:1000 dilution in Tris-buffered saline; host: rabbit). The secondary antibody used was anti-rabbit IgG (horseradish peroxidase, 1:12,000 dilution in Tris-buffered saline; purchased from Santa Cruz, Heidelberg, Germany).

\section{Determination of TGF- $\beta 1$ Production}

TGF- $\beta_{1}$ concentration in culture supernatant was determined by specific enzyme-linked immunosorbent assay (ELISA) (R\&D Systems Europe Ltd., Abingdon, UK). This assay has less than $1 \%$ cross-reactivity with TGF- $\beta 1$ and TGF- $\beta 3$. Briefly, high protein-binding 96-well plates were coated with $2 \mu \mathrm{g} / \mathrm{mL}$ of TGF- $\beta$ capture antibody in PBS, overnight at room temperature. Wells were washed, and the plate was incubated for 1 hour at room temperature with block buffer (5\% Tween 20, 0.05\% sodium azide) and then washed before addition of TGF- $\beta$ standards and cell culture supernatant samples. Cells were grown to confluence in $35-\mathrm{mm}$ dishes and growth arrested for 48 hours. Cells were then treated as described in the figure legends. Twenty microliters of $1 \mathrm{~mol} / \mathrm{L}$ $\mathrm{HCl}$ was then added to $100-\mu \mathrm{L}$ samples of cell supernatants to acid-activate latent TGF- $\beta_{1}$, and the samples were incubated for 10 minutes at room temperature. The acid-activated samples were neutralized with $20 \mu \mathrm{L}$ of $1.2 \mathrm{~mol} / \mathrm{L} \mathrm{NaOH}$ and $0.5 \mathrm{~mol} / \mathrm{L}$ HEPES. Samples and standards were then added to the plate and incubated for 2 hours at room temperature. The plate was washed, and detection antibody was added at $300 \mathrm{ng} / \mathrm{mL}$ in reagent diluent $(1.4 \%$ delipidized bovine serum albumin $/ 0.05 \%$ Tween 20 in PBS). The plate was then incubated for a further 2 hours at room temperature and washed again. Streptavidin-horseradish peroxidase $(0.5 \%$ in PBS/Tween) was added to each well; the plate was incubated in the dark for 20 minutes and then washed. Substrate solution (tetramethylbenzidine $/ \mathrm{H}_{2} \mathrm{O}_{2}$ ) was added to the wells, and the plate was incubated in the dark for 20 minutes before the addition of stop solution. The intensity of the resulting color was measured in optical density units using a spectrophotometer at $450 \mathrm{~nm}$. The TGF- $\beta_{1}$ concentration was calculated by comparing the absorbance of the sample against a reference curve prepared from the reagent blank and the standards.

\section{Visualization of Pericellular HA by Particle Exclusion Assay}

In some experiments, the exclusion of horse erythrocytes was used as a means to visualize the HA pericellular coat. As described in our previous work, ${ }^{49}$ formalized horse erythrocytes were washed in PBS and centrifuged at $1000 \times g$ for 7 minutes at $4{ }^{\circ} \mathrm{C}$. The pellet was resuspended in serum-free medium at an approximate density of $1 \times 10^{8}$ erythrocytes/ $\mathrm{mL}$. Five hundred microliters of this suspension was added to each $35-\mathrm{mm}$ dish that contained subconfluent cells and swirled gently for even distribution. The dishes were incubated at $37^{\circ} \mathrm{C}$ for 15 minutes to allow the erythrocytes to settle around the cells. On settling, the erythrocytes were excluded from zones around the cells with HA pericellular coats. This was viewed under the microscope as an area of erythrocyte exclusion. Zones of exclusion were visualized on an Axiovert 135 inverted microscope (Zeiss, Germany).

\section{Migration Studies}

Fibroblast migration was examined using a scratch-wound assay as previously described. ${ }^{42}$ Briefly, a denuded area was generated on quiescent cell monolayers of fibroblasts by scratching with a sterile pipette tip. The monolayer was washed twice with PBS and then incubated with medium containing either serum-free medium alone or serum-free medium containing $1 \mathrm{ng} / \mathrm{mL}$ of IL- $1 \beta$. To quantify migration, closure of the denuded area was monitored using an Axiovert 100M inverted microscope fitted with a digital camera (ORCA-1394; Hamamatsu Photonics, K.K., Hamamatsu, Japan) and images of the denuded area captured as a digitalized sequence. The rate of motility of the cells was calculated as the number of cells entering the central denuded area at $0,24,48,72$, and 96 hours. Cell number was expressed as cells per square millimeter of the original denuded area.

\section{Analysis of Cell Proliferation}

The commercially available AlamarBlue Proliferation Assay (Biosource, Paisley, UK) was used to assess cell growth. 

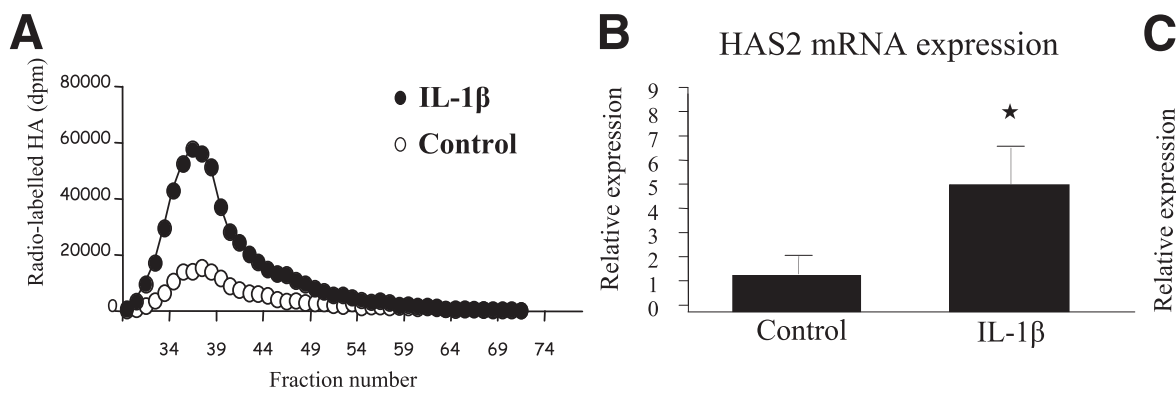

C HAS3 mRNA expression

Figure 1 HA generation in lung fibroblasts. A: Size exclusion chromatography profile of HA purified from lung fibroblasts. Confluent monolayers of lung fibroblasts were growth arrested in serum-free medium for 48 hours. The medium was then changed to contain either serum-free medium containing $20 \mu \mathrm{Ci} / \mathrm{mL}$ of $\left[{ }^{3} \mathrm{H}\right]$-glucosamine alone (control) or serum-free medium containing both $1 \mathrm{ng} / \mathrm{mL}$ of IL-1 $\beta$ and $20 \mu \mathrm{Ci} / \mathrm{mL}$ of $\left[{ }^{3} \mathrm{H}\right]$-glucosamine, and the incubations were continued for 72 hours. The radiolabeled HA was isolated from the conditioned medium and subjected to size-exclusion chromatography. B and C: HAS2 and HAS3 mRNA expression in fibroblasts, respectively. Confluent monolayers of lung fibroblasts were growth arrested in serum-free medium for 48 hours. The medium was then replaced with either serum-free medium alone (control) or serum-free medium containing $1 \mathrm{ng} / \mathrm{mL}$ of IL- $1 \beta$, and the incubations continued for 72 hours. HAS2 mRNA (B) and HAS3 mRNA (C) expression were then assessed by RT-qPCR. Ribosomal RNA expression was used as an endogenous control, and gene expression was assessed relative to the control samples. The experiment represents the mean of three samples for each experimental condition, and statistical analysis was performed using paired Student's $t$-test with $P<0.05$ considered to be significant.

Comparison of this assay with ${ }^{3} \mathrm{H}$-thymidine incorporation as an assessment of proliferation has been previously verified. ${ }^{50}$ The AlamarBlue assay uses an oxidation-reduction indicator that fluoresces in response to chemical reduction of growth medium that results from cell growth and metabolism and demonstrates a linear relationship between the magnitude of fluorescence and cell number and viability. For this assay, the cells were grown in 35-mm dishes and assessed at subconfluence after a 24- or 48-hour period of growth arrest as indicated. After appropriate stimulation of cells (as indicated in individual figure legends), $10 \%$ AlamarBlue was added to the cell culture medium for 1 hour at $37^{\circ} \mathrm{C}$. Hundredmicroliter aliquots of the conditioned medium were then removed and added to a clear 96-well plate. Subsequently, fluorescence was measured in a Fluostar optima fluorescence meter (BMG Lab Technologies, Ayelsbury, UK) with excitation wavelength at $540 \mathrm{~nm}$ and emission wavelength at 590 $\mathrm{nm}$, and the results expressed in arbitrary fluorescence units.

\section{Assessment of Monocyte-Fibroblast Binding}

U937 cells were grown in suspension culture in RPMI medium supplemented with L-glutamine and penicillin/ streptomycin containing 5\% fetal bovine serum until an appropriate cell density of $1 \times 10^{6}$ cells $/ \mathrm{mL}$ was achieved. These cells were then centrifuged and resuspended in fibroblast growth medium (DMEM/F12) and incubated with fibroblasts grown in monolayer to $70 \%$ confluence in $35-\mathrm{mm}$ dishes. Before addition of the U937 cells, the fibroblasts were treated as described in individual figure legends. After appropriate periods of incubation (as outlined in the figure legends), the cultures were washed 10 times with $2 \mathrm{~mL}$ of PBS to remove any unbound U937 cells. Subsequently, the cells were lyzed with Tri-reagent and RT-qPCR was performed for CD45 mRNA expression as described. RTqPCR of CD45 mRNA expression of monolayers of lung fibroblasts alone was also performed to confirm that CD45 mRNA expression was not present in lung fibroblasts.

\section{Statistical Analysis}

Paired Student's $t$-tests were performed for experiments with only one variable. For experiments with multiple variables, one-way analysis of variance was used to identify statistical differences, followed by paired Student's $t$-tests. The results are expressed as means \pm SE. All data were analyzed using SPSS statistical software version 14.0 (SPSS Inc., Chicago, IL), and $P<0.05$ was considered significant.

\section{Results}

\section{IL-1 $\beta$-Dependent HA Generation in Fibroblasts Is HAS2 Dependent}

Labeling of fibroblasts with $\left[{ }^{3} \mathrm{H}\right]$-glucosamine and subsequent analysis of HA generation using ion exchange and size exclusion chromatography demonstrated that there was between twofold to threefold more high-molecular-weight HA generated in fibroblasts stimulated with IL- $1 \beta$ compared with fibroblasts incubated with serum-free medium alone (Figure 1A). qPCR was then used to assess HAS expression in lung fibroblasts. HAS2 was the principle HAS enzyme present in lung fibroblasts, and stimulation with IL- $1 \beta$ resulted in a twofold to threefold increase in HAS2 expression $(P=$ 0.001) (Figure 1B). HAS1 was not expressed (data not shown) and HAS3 expression was not up-regulated in response to $\mathrm{IL}-1 \beta$ in lung fibroblasts (Figure 1C).

The IL-1 $\beta$-Dependent HA Matrix Is Distinct from the HA Matrix Formed After TGF- $\beta 1$ Stimulation

The red cell exclusion assay was used to confirm the presence of HA coats in fibroblasts after TGF- $\beta 1$ and IL- $1 \beta$ stimulation. As previously shown, ${ }^{51}$ compared with unstimulated fibroblasts (Figure 2A), both TGF- $\beta 1$ (Figure 2B) and IL-1 $\beta$ (Figure 2C) induced HA coat assembly in fibroblasts (denoted by the red cell free zone surrounding the fibroblasts). 

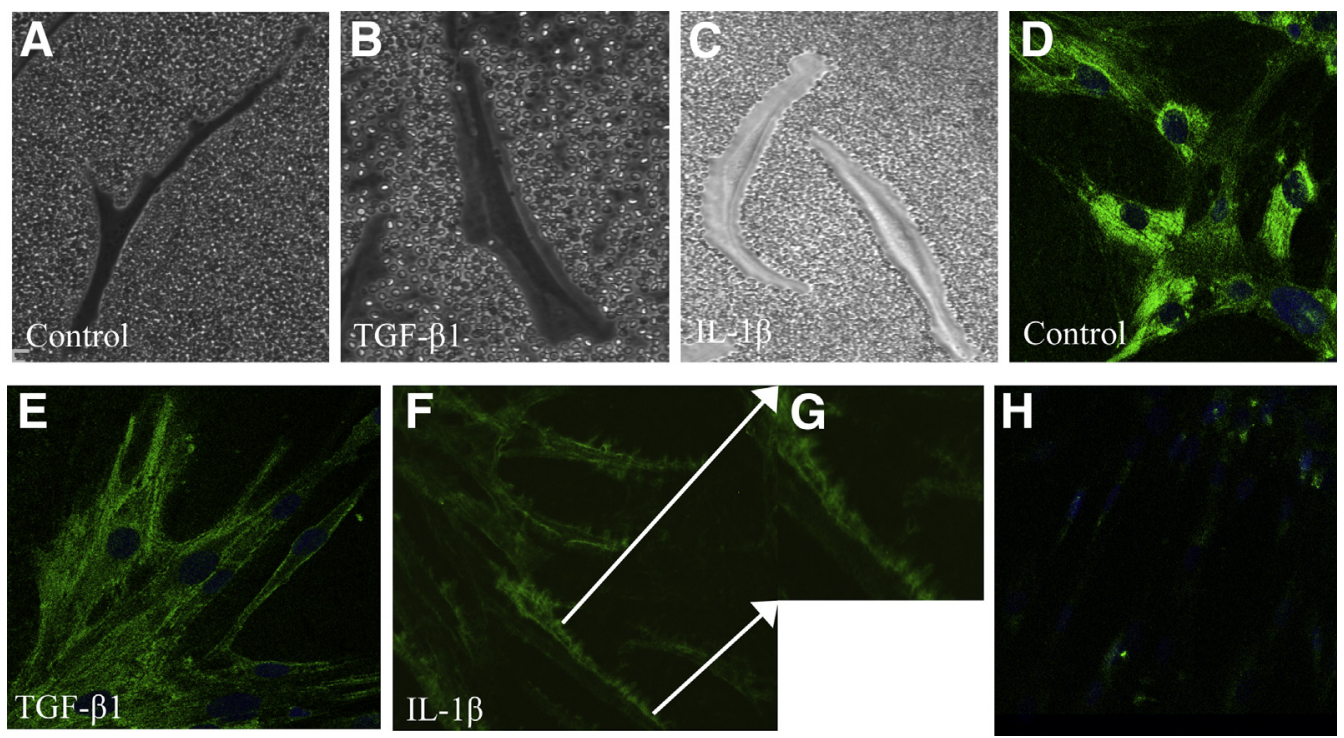

Figure 2 Localization of pericellular HA in fibroblasts. Subconfluent monolayers of lung fibroblasts were growth arrested for 48 hours. The cells were either incubated with serum-free medium alone (A and $\mathbf{D})$, serum-free medium containing $10 \mathrm{ng} / \mathrm{mL}$ of TGF- $\beta 1$ ( $\mathbf{B}$ and $\mathbf{E}$ ), or serum-free medium containing $1 \mathrm{ng} / \mathrm{mL}$ of IL-1 $\beta$ (C, F, and $\mathbf{G})$ for 72 hours. A-C: The subconfluent monolayers of growth arrested cells were stimulated with either $10 \mathrm{ng} / \mathrm{mL}$ of TGF- $\beta 1$ (B), $1 \mathrm{ng} / \mathrm{mL}$ of IL-1 $\beta(\mathbf{C})$, or serum-free medium alone (A) for 72 hours. Formalized horse erythrocytes were then added to visualize the HA pericellular coat. Cells with large HA coats demonstrate a red-cell free area surrounding the cell. D-H: The cells were fixed and HA was detected as described in Materials and Methods by the addition of bHABP and fluorescent avidin-D. G: An enlarged image of the section marked by arrows in $\mathbf{F}$. H: The primary antibody was replaced with nonimmune mouse serum as a control. DAPI was used as a nuclear stain and is depicted in blue. Original magnification: $\times 200(\mathbf{A}-\mathbf{H})$.

Immunocytochemical analysis was then used to assess HA staining in lung fibroblasts. In unstimulated fibroblasts, there was dense perinuclear and intracellular HA staining demonstrated (Figure 2D). In TGF- $\beta 1$-stimulated fibroblasts, there was a HA pericellular coat present that closely surrounded the cell membranes of each individual cell (Figure 2E). In comparison, after IL-1 $\beta$ stimulation, the HA was localized to the outer cell membrane and appeared to protrude from the cell membrane in a linear fashion (Figure 2F). This was best demonstrated in the enlarged image (Figure $2 \mathrm{G}$ ). Incubation with nonimmune mouse serum was used as a control (Figure 2H).

\section{CD44 and ICAM-1 Are Induced and Redistributed After IL-1 $\beta$ Stimulation in Fibroblasts}

The HA receptor, CD44, plays an important role in the propagation of intracellular signals after its binding to HA and thereby plays a central role in mediating the functions of HA. qPCR was used to compare the effects of TGF- $\beta 1$ stimulation versus the effects of IL- $1 \beta$ stimulation on CD44 mRNA expression in lung fibroblasts. ICAM-1 is also known to bind HA and initiate propagation of intracellular signals after HA-ICAM-1 binding. ${ }^{54,55}$ Therefore, the effect of TGF- $\beta 1$ and IL-1 $\beta$ stimulation on ICAM-1 expression in fibroblasts was also assessed. Stimulation of lung fibroblasts with TGF- $\beta 1$ significantly down-regulated both CD44 and ICAM-1 expression $(P<0.01$ and $P=0.03$, respectively) (Figure 3, A and B). In contrast, IL-1 $\beta$ induced CD44 expression by approximately 10 -fold in lung fibroblasts $(P<0.001)$ (Figure 3C). ICAM-1 expression was also shown to be significantly up-regulated by IL- $1 \beta$ stimulation $(P=0.02)$ (Figure 3D).

Protein expression and distribution of CD44 and ICAM-1 were assessed using immunocytochemistry. In unstimulated fibroblasts, CD44 was diffusely distributed (Figure 4A). In comparison, in IL-1 $\beta$-stimulated fibroblasts, the CD44 had a punctate distribution when viewed from above the cell
A
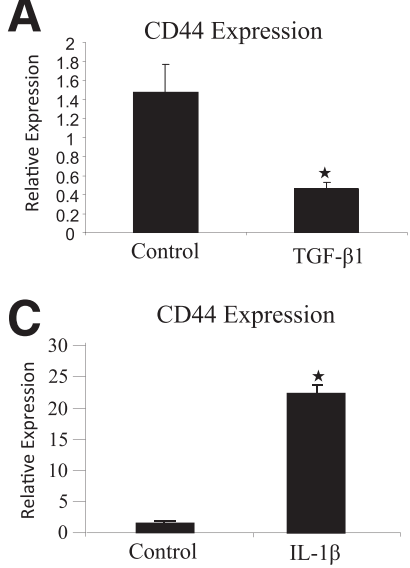

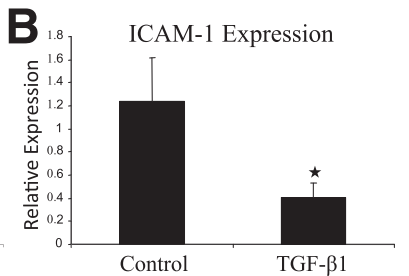

D ICAM-1 Expression

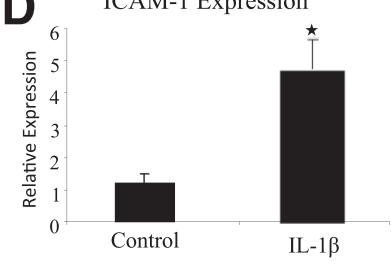

Figure 3 CD44 and ICAM-1 mRNA expression fibroblasts. Confluent monolayers of lung fibroblasts were growth arrested in serum-free medium for 48 hours. The medium was then replaced with either serum-free medium alone (control), serum-free medium containing $10 \mathrm{ng} / \mathrm{mL}$ of TGF- $\beta 1$ (A and B), or serum-free medium containing $1 \mathrm{ng} / \mathrm{mL}$ of IL-1 $\beta$ (C and $\mathbf{D})$. The incubations continued for 72 hours. CD44 (A and C) and ICAM-1 (B and D) mRNA expression were then assessed by RT-PCR as described in Materials and Methods. The experiment represents the mean of three samples for each experimental condition, and statistical analysis was performed using paired Student's $t$-test with $P<0.05$ considered as significant. 

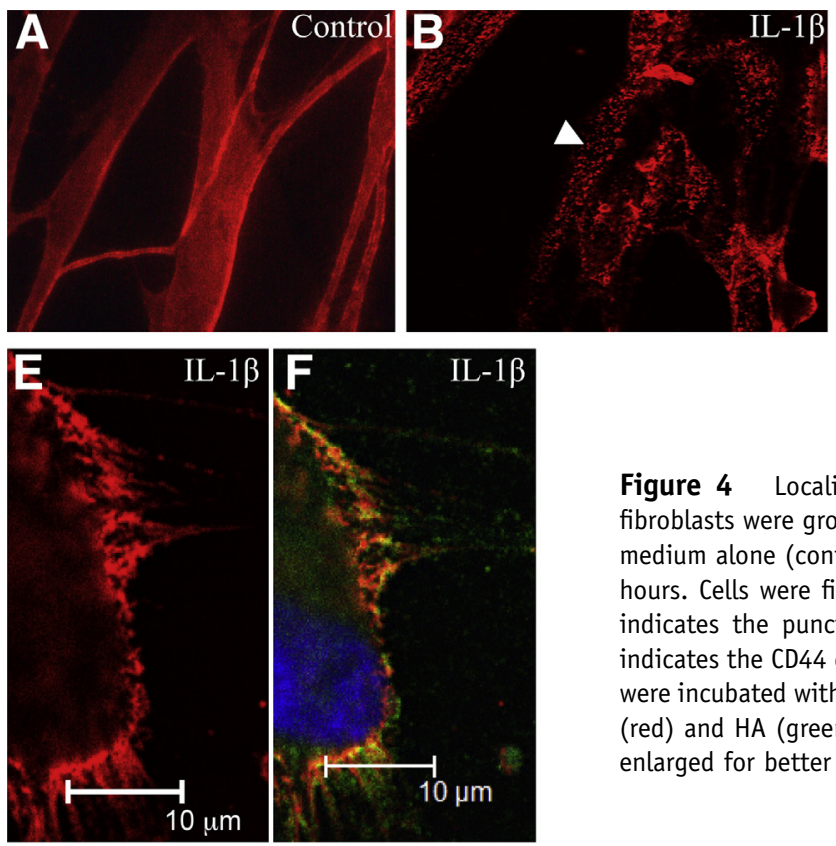

$\mathrm{HA}$ and CD44 co-

localised images
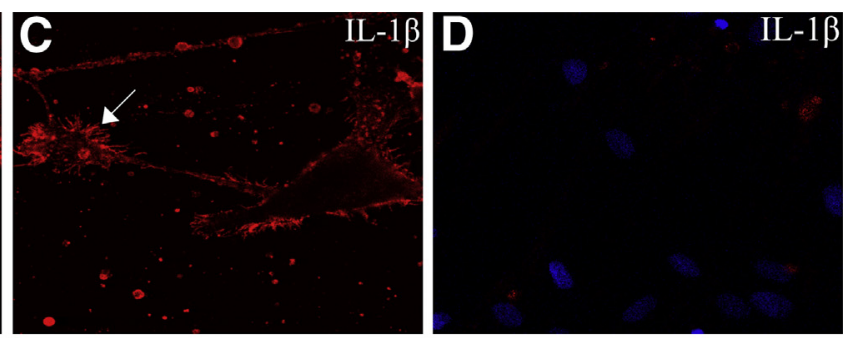

Figure 4 Localization of CD44 and HA in fibroblasts. Subconfluent monolayers of lung fibroblasts were growth arrested for 48 hours. The cells were either incubated with serum-free medium alone (control) (A) or serum-free medium containing $1 \mathrm{ng} / \mathrm{mL}$ of IL-1及 (B-F) for 72 hours. Cells were fixed and stained for the expression of CD44 (red) (A-E). The arrowhead indicates the punctate distribution of CD44 when viewed from above the cell. The arrow indicates the CD44 containing cell protrusions that project form the cell surface. The cells in D were incubated with nonimmune mouse serum as a control. The cells in $\mathbf{F}$ were stained for CD44 (red) and HA (green) with co-localized areas depicted in yellow. The images in $\mathbf{E}$ and $\mathbf{F}$ were enlarged for better view of the cell membranes. Original magnification: $\times 400$ (E and $\mathbf{F}$ ).

(Figure 4B). However, when viewed at the cell periphery or in cross section, this punctate staining appeared to be the result of CD44 being concentrated and localized within small membrane protrusions or spiculations projecting from the cell surface (Figure 4C). The protrusions varied in length between approximately 0.5 and $10 \mu \mathrm{m}$ and appeared to correspond to the areas where HA protruded from the cell membrane as shown in the magnified images (Figure 4, E and F). Incubation with nonimmune mouse serum was used as a control (Figure 4D).
Immunocytochemical staining for ICAM-1 (green staining) (Figure 5, A-C) demonstrated that similar to CD44, ICAM-1 has a diffuse distribution in unstimulated fibroblasts (Figure 5A). In keeping with its mRNA expression demonstrated in Figure 3B, ICAM-1 has low level staining, indicating reduced protein expression in fibroblasts stimulated with TGF- $\beta 1$ (Figure 5B). Furthermore, it remains diffusely distributed within the cell membrane in TGF$\beta 1-$ stimulated cells (Figure 5B). After IL- $1 \beta$ stimulation, ICAM-1 again follows a similar pattern of distribution to
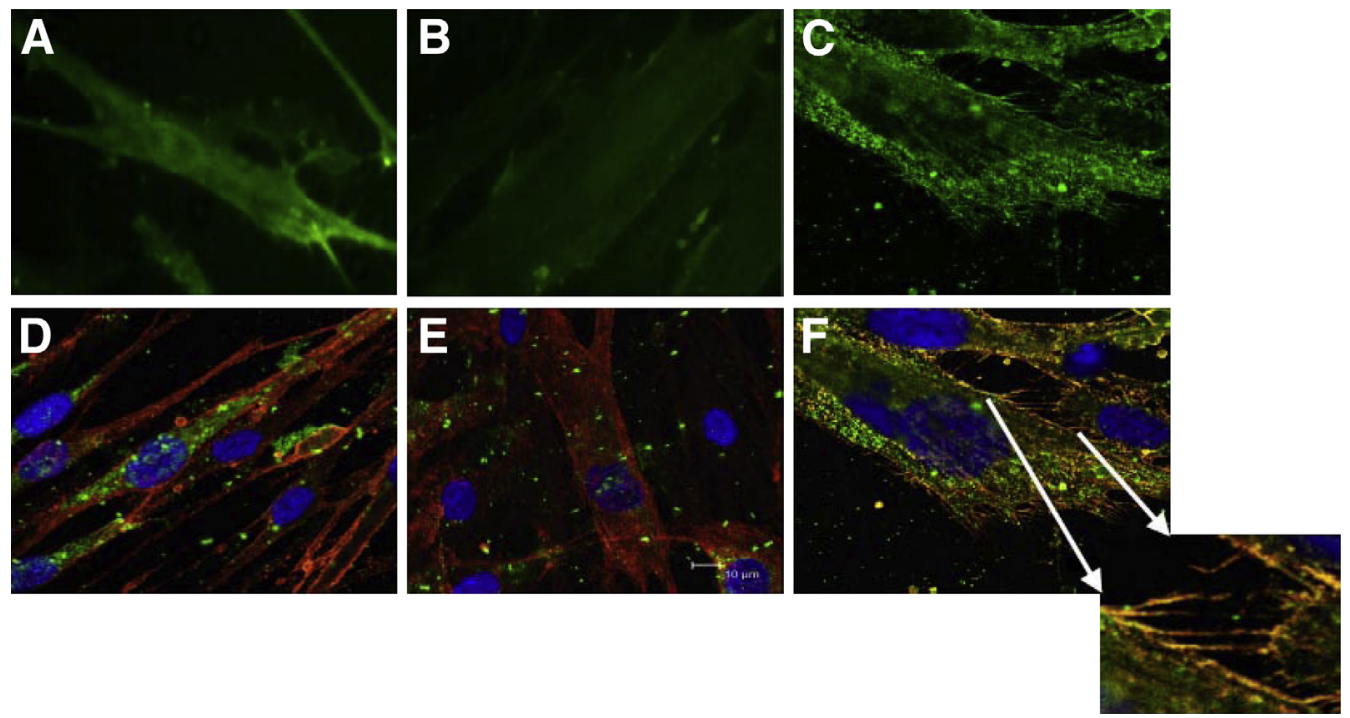

Figure 5 Localization of CD44 and ICAM-1 in fibroblasts. Subconfluent monolayers of lung fibroblasts were growth arrested for 48 hours. The cells were then incubated with either serum-free medium alone (control) (A and $\mathbf{D}$ ), serum-free medium containing $10 \mathrm{ng} / \mathrm{mL}$ of TGF- $\beta 1$ (B and $\mathbf{E}$ ), or serum-free medium containing $1 \mathrm{ng} / \mathrm{mL}$ of IL-1 $\beta$ (C and $\mathbf{F}$ ) for 72 hours. A-C: Cells were fixed and stained for the expression of ICAM-1 (green). D-F: Cells were fixed and stained for ICAM-1 (green) and CD44 (red). Association between CD44 and ICAM-1 was then examined by merging individual images. Any evidence of colocalization was demonstrated in yellow. Original magnification: $\times 400(\mathbf{A}-\mathbf{F})$. Arrows indicate the location of the enlarged image. Original magnification: $\times 400$. 
A

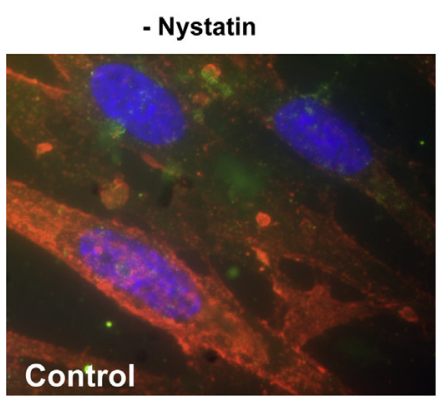

CD44 and ICAM-1 Staining

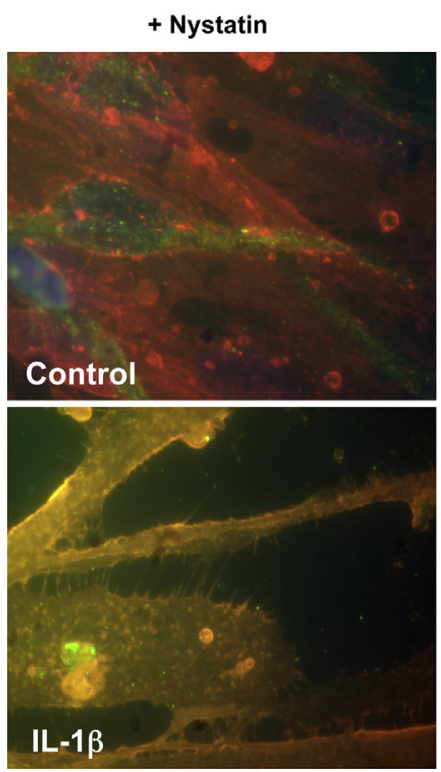

B CD44 and CtxB Staining

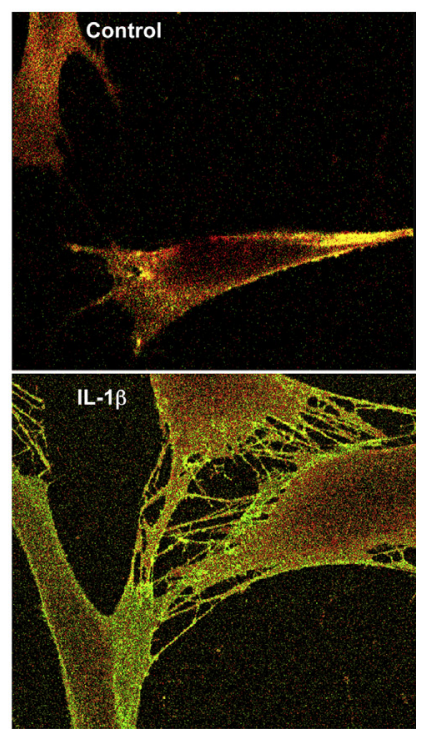

Figure 6 Localization of CD44 within the cell membrane. A: Effect of nystatin treatment on IL-1 $\beta$-dependent membrane protrusions and CD44 and ICAM-1 membrane localization. Subconfluent monolayers of lung fibroblasts were growth arrested for 48 hours. The cells were then either incubated with serum-free medium containing $1 \mathrm{ng} / \mathrm{mL}$ of IL-1 $\beta$ or serum-free medium alone and incubations continued for 72 hours. Another group of cells were treated similarly except the fibroblasts were pretreated with $50 \mu \mathrm{g} / \mathrm{mL}$ of nystatin at $37^{\circ} \mathrm{C}$ for 1 hour before treatment of cells with either serum-free medium alone or serum-free medium containing $1 \mathrm{ng} / \mathrm{mL}$ of IL-1 $\beta$. The cells were then fixed and immunocytochemistry used to stain for CD44 (red) and ICAM-1 (green). Association between CD44 and ICAM-1 was then examined by merging of individual images. Any evidence of colocalization was demonstrated in yellow. B: Association between CD44 (green) and the lipid-raft marker CtxB (red). Subconfluent monolayers of lung fibroblasts were growth arrested for 48 hours. The cells were then either incubated with serum-free medium containing $1 \mathrm{ng} / \mathrm{mL}$ of IL-1 $\beta$ or serum-free medium alone and incubations continued for 72 hours. The cells were then incubated for 5 minutes with $1 \mu \mathrm{g} / \mathrm{mL}$ of both a primary FITC-conjugated anti-CD44 antibody (green) and $1 \mu \mathrm{g} / \mathrm{mL}$ of a primary Alexa Fluor-conjugated anti-CtxB antibody (red). The cells were then washed with serum-free culture medium three times and viewed using a Leica SP2 confocal microscope. Association between these two proteins was depicted as yellow staining in merged images. Original magnification: $\times 400$ (A and B).

CD44, being redistributed in a punctate manner, concentrated within the membrane protrusions projecting from the cell surface (Figure 5C). Dual staining for ICAM-1 (green) and CD44 (red) demonstrated that in unstimulated fibroblasts (Figure 5D) and TGF- $\beta 1-$ stimulated fibroblasts (Figure 5E), there was little co-localization between CD44 and ICAM-1. However, after IL-1 $\beta$ stimulation, it was apparent that CD44 and ICAM-1 were co-localized within the membrane protrusions (depicted in yellow) (Figure 5F).

The distribution of CD44 within lipid-raft domains of the cell membrane was examined initially by disruption of the cholesterol-rich lipid raft domains by pretreatment of fibroblasts with $50 \mu \mathrm{g} / \mathrm{mL}$ of nystatin at $37^{\circ} \mathrm{C}$ for 1 hour before treatment of cells with either serum-free medium alone or serum-free medium containing $1 \mathrm{ng} / \mathrm{mL}$ of IL- $1 \beta$. Immunohistochemical (IHC) analysis for CD44 and ICAM-1 in nystatin-untreated fibroblasts demonstrated no co-localization in unstimulated fibroblasts and co-localization between these two proteins in fibroblasts treated with IL-1 $\beta$ as previously shown (yellow staining). Pretreatment of fibroblasts with nystatin did not appear to affect protrusion formation in fibroblasts or influence co-localization between CD44 and ICAM-1 in the merged images (depicted by yellow staining in merged images) (Figure 6A). Subsequently, live unstimulated and IL- $1 \beta$-stimulated fibroblasts were simultaneously incubated with a FITC-conjugated primary anti-CD44 antibody and an Alexa Fluor 594 conjugated primary antibody against $\mathrm{CtxB}$, an established marker of lipid-raft microdomains. CtxB (red) and CD44 (green) staining was then viewed using a Leica SP2 confocal microscope and co-localization between these two proteins depicted as yellow staining in merged images. Unstimulated fibroblasts demonstrated marked yellow staining in merged images, indicating the likely presence of CD44 within lipidraft rich domains in these cells. After IL- $1 \beta$ stimulation, yellow staining within the merged images was less evident, indicating the likely movement of CD44 from the lipid-raft microdomains in these cells (Figure 6B).

\section{The Cellular Protrusions Formed After IL-1 $\beta$ Stimulation Are HA, HAS2, and CD44 Dependent}

The importance of HA in maintenance and formation of the membrane protrusions was initially assessed by treatment of the cells with either 4-methylumbelliferone (4MU) or bovine testicular hyaluronidase. 4MU has been shown to inhibit HAS and HAS activity by depletion of the UDP-glucuronic acid pool required to make $\mathrm{HA},{ }^{56}$ whereas hyaluronidase breaks down the extracellular HA, without influencing HAS activity or HA synthesis. Staining for HA (Figure 7A) and 
A

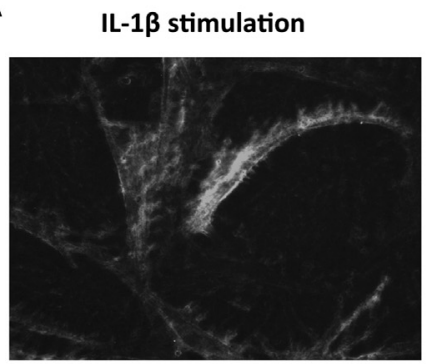

B

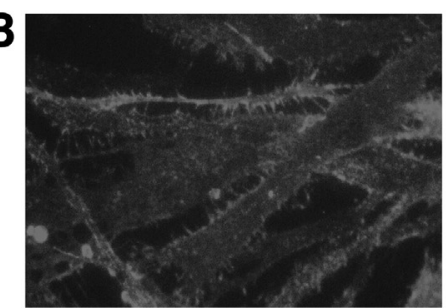

IL-1 $\beta+$

Hyaluronidase
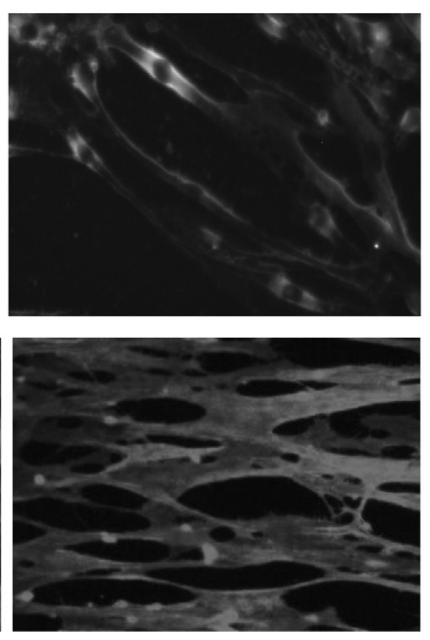

$\mathrm{IL}-1 \beta+4 \mathrm{MU}$
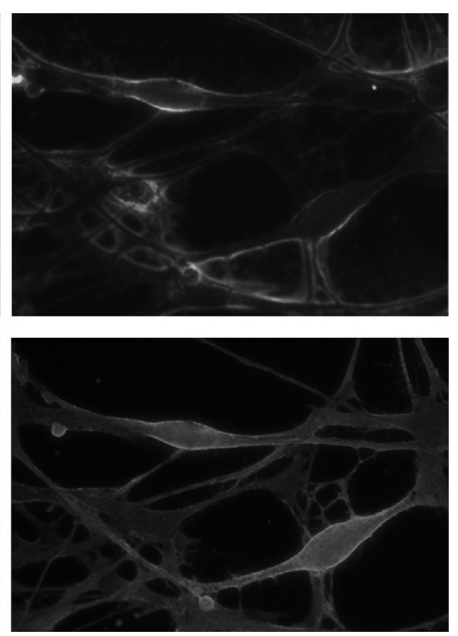

Figure 7 Effect of 4MU and hyaluronidase treatment on CD44 and HA localization in lung fibroblasts. Subconfluent monolayers of lung fibroblasts were growth arrested for 48 hours. The cells were then either incubated with serum-free medium containing $1 \mathrm{ng} / \mathrm{mL}$ of IL-1 $1 \beta$, serum-free medium containing $1 \mathrm{ng} / \mathrm{mL}$ of IL-1 $\beta$, and $0.5 \mathrm{mmol} / \mathrm{L} 4 \mathrm{MU}$ or serum-free medium containing $1 \mathrm{ng} / \mathrm{mL}$ of IL-1 $\beta$ and $200 \mu \mathrm{g} / \mathrm{mL}$ of bovine testicular hyaluronidase. Cells were fixed as described in Materials and Methods and the expression of HA (A) and CD44 (B) were identified by addition of appropriate primary and fluorescent secondary antibodies. Original magnification: $\times 200$.

CD44 (Figure 7B) showed that the membrane projections and the HA protrusions disappeared after treatment with either bovine testicular hyaluronidase or 4MU.

siRNAs were then used to knockdown targeted gene expression of HAS2 and CD44 to assess the dependence of the IL-1 $\beta$-dependent protrusions on these proteins. Figure 8A shows successful knockdown of HAS2 and CD44 mRNA expression, respectively, after siRNA treatment compared with the scrambled controls $(P<0.05$ for both experiments). Figure 8, B-I, shows the effect of knockdown of these genes on the IL-1 $\beta$-dependent protrusions as assessed by CD44 staining and HA staining. The results indicated that although transfection with scrambled controls had no effect on the membrane protrusions (Figure 8, D and E), knockdown of either CD44 (Figure 8, F and G) or HAS2 (Figure 8, H and I) gene expression attenuated formation of the protrusions.

\section{TSG-6 Is the Key Difference between the}

IL-1 $\beta$-Dependent and the TGF- $\beta 1$-Dependent HA Pericellular Matrix

TSG-6 is an HA binding protein that has previously been shown to be up-regulated in various inflammatory conditions and has been thought to exert some anti-inflammatory actions. ${ }^{57,58}$ Several studies have demonstrated that the compact HA pericellular coat assembled by several cell types is dependent on TSG-6.51,52,59,60 In particular, we have previously shown that TSG-6 is an essential component of the HA coat necessary for TGF- $\beta 1-$ driven phenotypic differentiation in fibroblasts. ${ }^{51,52}$ The importance of TSG-6 in the IL-1 $\beta$-dependent HA pericellular protrusions was therefore also investigated. The effect of IL-1 $\beta$ stimulation on TSG-6 production by fibroblasts was initially assessed. These data indicated that, similar to TGF- $\beta 1$, IL-1 $\beta$ also markedly induced TSG-6 mRNA expression $(P<0.001)$ (Figure 9A) and TSG-6 protein expression in fibroblasts $(P<0.05)$ (Figure 9B). Subsequently, siRNAs were used to knockdown targeted gene expression of TSG-6 to assess the dependence of the IL-1 $\beta$-dependent protrusions on TSG-6 (Figure 9C). However, in contrast to the reported effect of TSG-6 siRNA on the TGF- $\beta 1$-dependent HA matrix, knockdown of TSG-6 did not appear to affect the formation of the IL-1 $\beta$-dependent membrane protrusions (Figure 9D).

\section{HA/CD44-Dependent Protrusions Are Not Involved in Fibroblast Migration or Proliferation}

Stimulation of fibroblasts with IL- $1 \beta$ is not clearly linked to the acquisition of a myofibroblast phenotype. Hence, we subsequently attempted to outline the function of IL-1 $\beta$ and of the IL-1 $\beta$-dependent protrusions in fibroblasts. Initially, we attempted to determine whether the IL- $1 \beta$-dependent protrusions were involved in fibroblast migration. The effect of IL-1 $\beta$ stimulation on fibroblast migration was therefore assessed. A scratch-wound method was used as a migration assay. However, no obvious differences in fibroblast migration were observed in unstimulated and IL- $1 \beta$-stimulated fibroblasts (data not shown).

To determine whether the IL-1 $\beta$-dependent protrusions were involved in fibroblast proliferation, the effect of IL-1 $\beta$ on fibroblast proliferation was also assessed (Figure 10). These results demonstrated that IL- $1 \beta$ stimulation resulted in the induction of fibroblast proliferation (untransfected and scrambled graphs) $(P<0.05$ for both sets of samples). The fibroblasts treated with CD44 siRNA, however, still 

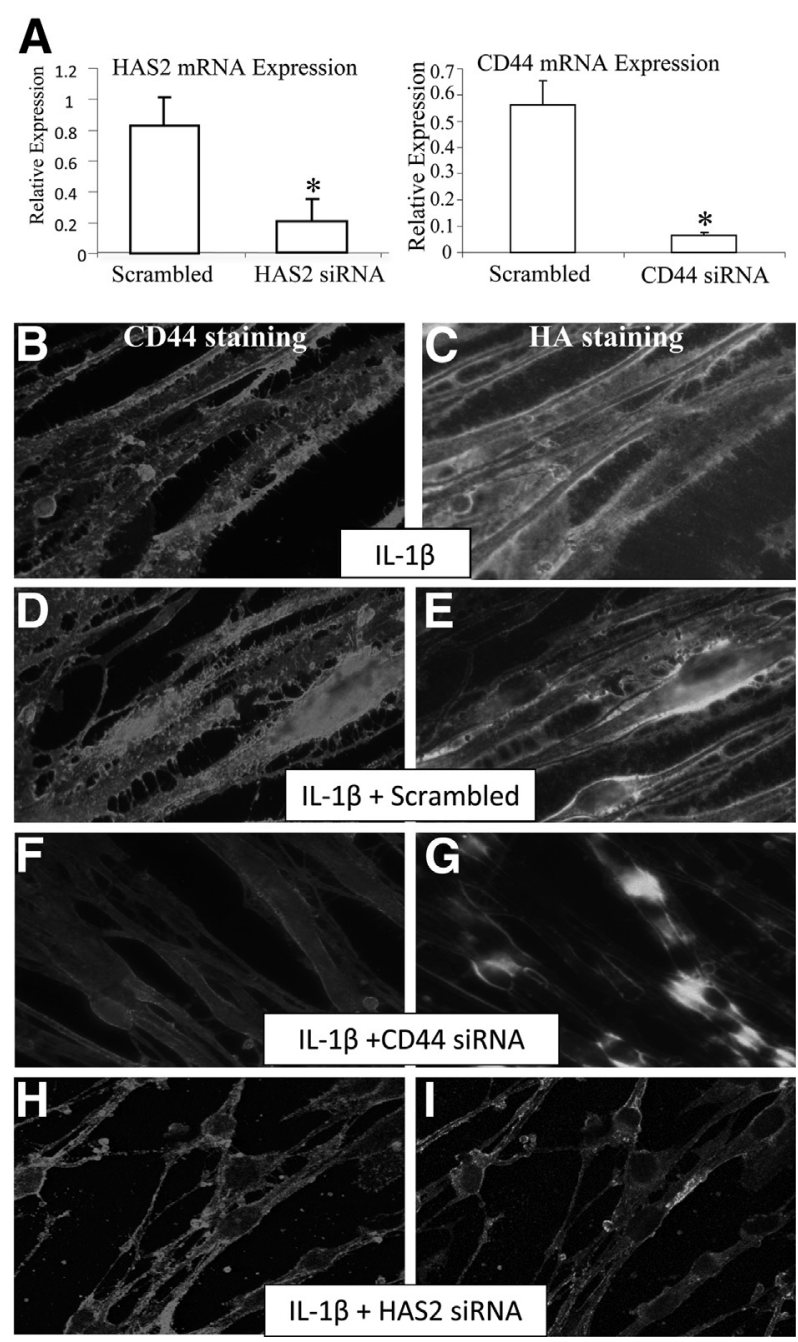

Figure 8 Effect of HAS2 and CD44 siRNA treatment on CD44 and HA localization in lung fibroblasts. A: HAS2 and CD44 mRNA expression. Lung fibroblasts were transfected with either HAS2 or negative control (scrambled) siRNA or they were transfected with CD44 or scrambled siRNA and incubated for 24 hours. To confirm HAS2 and CD44 knockdown, mRNA extraction was performed and HAS2 and CD44 expression was assessed by RT-qPCR. The results are expressed as means \pm SE of three experiments. Statistical analysis was performed using paired Student's $t$-test with ${ }^{*} P<0.05$ considered as significant. B-I: Localization of HA and CD44. In parallel experiments, the effect of HAS2 and CD44 knockdown on IL$1 \beta$-dependent membrane protrusions was assessed by IHC analysis of $\mathrm{HA}$ and CD44. The siRNAs were incubated with the cells in serum-free medium for 24 hours. Subsequently, either serum-free medium or serum-free medium containing $1 \mathrm{ng} / \mathrm{mL}$ of IL-1 $\beta$ was incubated with the cells for a further 72 hours, before fixation and staining of the cells with appropriate antibodies. Original magnification: $\times 200(B-I)$.

demonstrated significant induction of proliferation after stimulation with IL-1 $\beta(P=0.031)$. This indicated that inhibition of protrusion formation using CD44 siRNA (as demonstrated in Figure 8) did not prevent IL-1 $\beta$-induced proliferation, thereby demonstrating that protrusions were not involved in IL-1 $\beta$-dependent induction of proliferation. Furthermore, this indicates that IL- $1 \beta$-dependent fibroblast proliferation is independent of CD44 itself.

\section{HA/CD44-Dependent Protrusions Enhance} IL-1 $\beta$-Dependent Fibroblast-Monocyte Binding

Immunocytochemical staining for HA, CD44, and DAPI (nuclear stain) was performed to visualize the numbers of monocytes bound to fibroblasts after IL- $1 \beta$ stimulation. The results demonstrated that unstimulated fibroblasts (larger nuclei) bind considerably fewer monocytes (arrowheads, smaller nuclei) than the IL-1 $\beta$-stimulated fibroblasts. The IL-1 $\beta$-stimulated cells also seemed to have much greater HA staining (green) (Figure 11A). A high-magnification image of this fibroblast-monocyte interaction at the site of protrusions is shown in Figure 11B.

qPCR for CD45 mRNA expression for fibroblast cultures alone was subsequently performed to confirm that CD45 mRNA was undetectable in either unstimulated (control) fibroblasts or fibroblasts stimulated with IL-1 $\beta$ for 72 hours. In this experiment, mRNA expression of CD45 in fibroblasts was compared with mRNA expression in U937 cells as a positive control to confirm functionality of the qPCR assay (Figure 11C). Fibroblast-monocyte binding was then quantitatively assessed by performing qPCR for CD45 mRNA expression on fibroblast-monocyte co-cultures. CD45 mRNA expression was assessed after IL-1 $\beta$ stimulation in fibroblast-monocyte co-cultures (Figure 11D). The results demonstrated increased CD45 mRNA expression after 24,48 , and 72 hours of IL- $1 \beta$ stimulation, confirming that IL-1 $\beta$ increased fibroblast-monocyte binding.

To assess whether the IL-1 $\beta$-dependent protrusions were directly involved in fibroblast-monocyte binding, fibroblasts were treated with CD44 siRNA, HAS2 siRNA, TSG-6 siRNA, 4MU, or hyaluronidase, and the effect on fibroblastmonocyte binding was demonstrated by assessment of CD45 mRNA (Figure 12). The results demonstrated that compared with untransfected fibroblasts and fibroblasts treated with scrambled control siRNA, fibroblasts treated with 4MU, hyaluronidase, CD44 siRNA, or HAS2 siRNA all showed attenuated CD45 expression after co-culture with monocytes $(P<0.05)$. However, fibroblasts treated with TSG-6 siRNA demonstrated CD45 expression comparable to the controls after co-culture with monocytes. Hence, targeting the components required for protrusion formation affected the levels of CD45 mRNA detected, indicating that the protrusions play a role in fibroblast-monocyte binding.

The IL-1 $\beta$-Driven Fibroblast Phenotype Is Resistant to TGF- $\beta 1$-Driven Fibroblast to Myofibroblast

\section{Differentiation}

Determination of TGF- $\beta 1$ production after IL- $1 \beta$-driven fibroblast monocyte binding was performed using ELISA. Fibroblasts stimulated with IL-1 $\beta$ alone for 72 hours did not show increased TGF- $\beta 1$ generation compared with unstimulated fibroblasts. Similarly, fibroblasts incubated with U937 cells alone without the presence of IL- $1 \beta$ did not demonstrate increased levels of TGF- $\beta 1$ production. Stimulation of 
fibroblasts with $1 \mathrm{ng} / \mathrm{mL}$ of IL- $1 \beta$ for 72 hours and subsequent incubation with U937 cells as outlined in Materials and Methods led to a significant increase in TGF- $\beta 1$ generation in the fibroblast-monocyte co-cultures $(P=0.032)$ (Figure 13A). In similar experiments, RT-qPCR was used to assess $\alpha$ SMA mRNA expression to investigate whether the increased generation of TGF- $\beta 1$ enhanced myofibroblast formation in the fibroblast cultures. However, these experiments demonstrated a statistically insignificant reduction in $\alpha$-SMA mRNA expression after IL- $1 \beta$ stimulation and incubation with U937 cells $(P=0.08)$ (Figure 13B). A further study was subsequently performed to assess the influence of exogenous TGF- $\beta 1$ stimulation in cells pretreated with IL-1 $\beta$. In these experiments, growth-arrested fibroblasts were initially treated with $1 \mathrm{ng} / \mathrm{mL}$ of IL- $1 \beta$ for
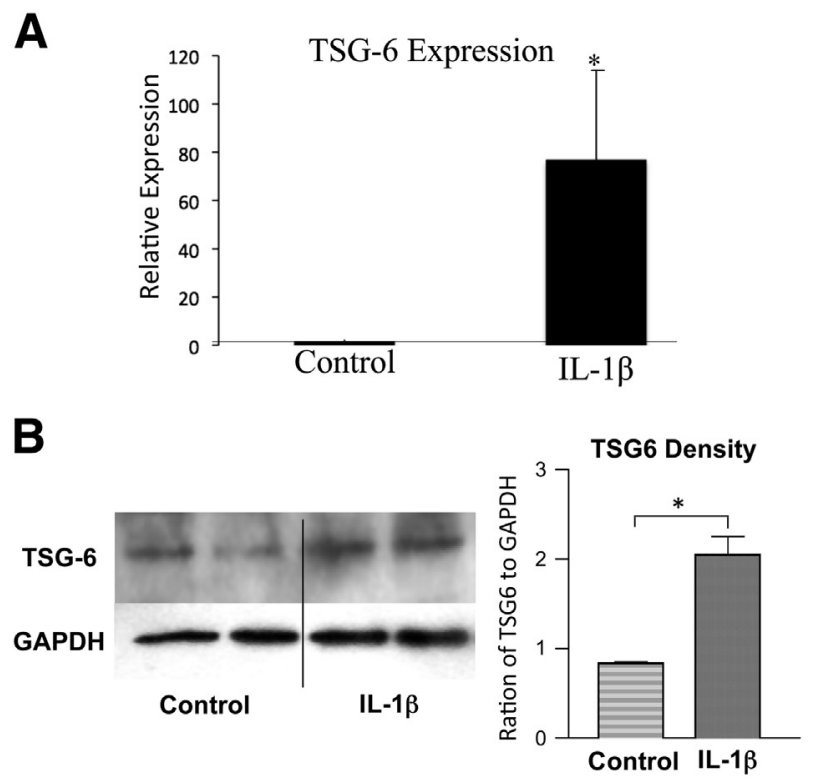

C
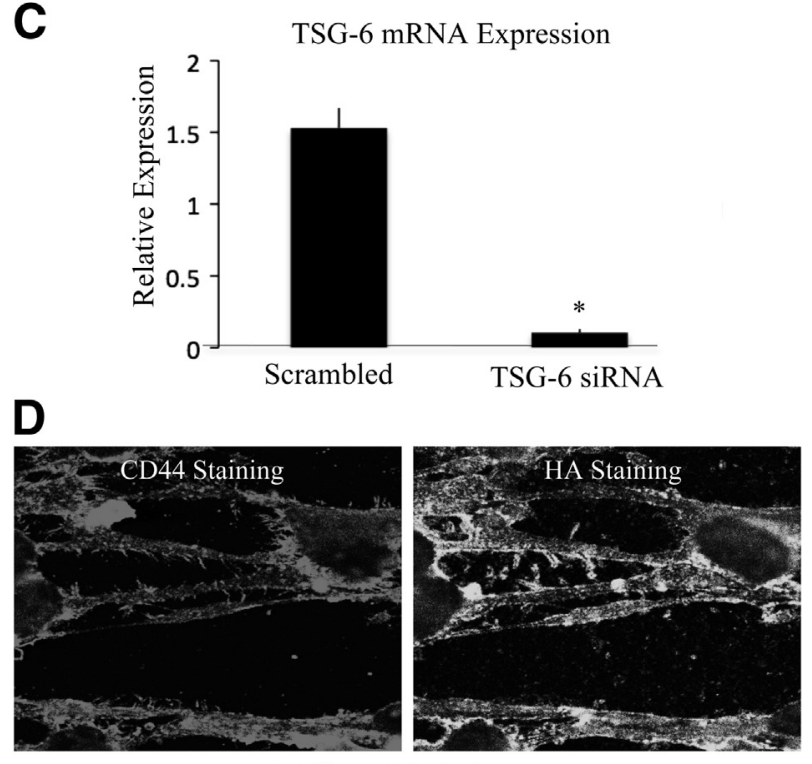

IL-1 + TSG-6 siRNA
72 hours and then with $10 \mathrm{ng} / \mathrm{mL}$ of TGF- $\beta 1$ for 72 hours and compared with unstimulated fibroblasts, fibroblasts treated with IL-1 $\beta$ alone, and fibroblasts treated with TGF- $\beta 1$ alone. This dose and duration of TGF- $\beta 1$ treatment have previously been reported to promote optimum and stable fibroblast to myofibroblast differentiation. ${ }^{50}$ These results demonstrated that, as expected, stimulation with TGF- $\beta 1$ alone led to statistically significant induction of $\alpha$ SMA mRNA expression $(P=0.002)$. Also, as expected, stimulation with IL-1 $\beta$ alone did not influence $\alpha$-SMA mRNA expression in fibroblasts. However, fibroblasts pretreated with IL- $1 \beta$ before TGF- $\beta 1$ stimulation did not demonstrate a significant increase in $\alpha$-SMA expression, suggesting attenuated fibroblast to myofibroblast differentiation in these cells (Figure 13C).

\section{IL-1 $\beta$ Promotes CD44-Dependent Fibroblast-Monocyte Binding Through MAPK/ERK1/2 Signaling in Fibroblasts}

The CD44 cytoplasmic tail can interact with the actin cytoskeleton and has been reported to have an important role in the activation of a number of signaling pathways, including the MAPK pathway. The involvement of MAPK/ ERK signaling in IL-1 $\beta$-driven changes in fibroblasts was initially investigated. A time course of IL- $1 \beta$ stimulation demonstrated increased phosphorylated ERK1/2 protein

Figure 9 Involvement of TSG-6 in IL-1 $\beta$-dependent protrusions. A: TSG-6 mRNA expression in fibroblasts. Confluent monolayers of lung fibroblasts were growth arrested in serum-free medium for 48 hours. The medium was then replaced with either serum-free medium alone (control) or serum-free medium containing $1 \mathrm{ng} / \mathrm{mL}$ of IL-1 $\beta$ and the incubations continued for 72 hours. TSG- 6 mRNA expression was then assessed by RT-qPCR. The experiment represents the mean of three samples for each experimental condition, and statistical analysis was performed using paired Student's $t$-test with ${ }^{*} P<0.05$ considered as significant. B: TSG- 6 protein expression in fibroblasts: Confluent monolayers of lung fibroblasts were growth arrested in serum-free medium for 48 hours. The medium was then replaced with either serum-free medium alone (control) or serum-free medium containing $1 \mathrm{ng} / \mathrm{mL}$ of IL- $1 \beta$ and the incubations continued for 72 hours. TSG-6 protein expression was assessed by Western blot analysis. GAPDH was used as a loading control. Scanning densitometry was used to correct TSG-6 expression against expression of GAPDH. Statistical analysis was performed using the paired Student's $t$-test, and statistical significance was taken as ${ }^{*} P<0.05$. The experiment represents the mean of three samples for each experimental condition. C: Confirmation of TSG-6 knockdown after use of TSG- 6 siRNA. Lung fibroblasts were transfected with TSG6 or negative control (scrambled) siRNA and incubated for 24 hours. To confirm TSG-6 knockdown, mRNA extraction was performed, and TSG-6 mRNA expression was assessed by RT-qPCR. The experiment represents the mean of three samples for each experimental condition, and statistical analysis was performed using paired Student's $t$-test with ${ }^{*} P<0.05$ considered as significant. D: Effect of TSG-6 knockdown on HA and CD44 localization. In parallel experiments, the effect of TSG-6 knockdown on IL$1 \beta$-dependent membrane protrusions was assessed by IHC analysis of HA and CD44. The siRNA was incubated with the cells in serum-free medium for 24 hours. Subsequently, either serum-free medium or serum-free medium containing $1 \mathrm{ng} / \mathrm{mL}$ of IL-1 $\beta$ was incubated with the cells for a further 72 hours before fixation and staining of the cells with appropriate antibodies. Original magnification: $\times 200$ (D). 


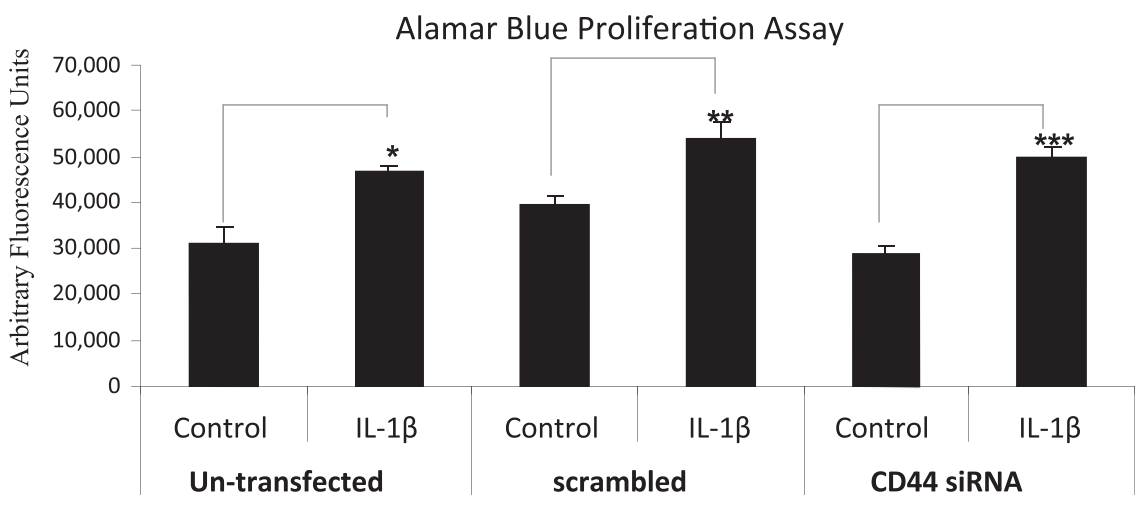

Figure 10 Effect of IL-1 $\beta$ and CD44 knockdown in fibroblast proliferation using Alamar Blue proliferation assay. Subconfluent monolayers of lung fibroblasts were either transfected with $\mathrm{CD} 44$ or negative control (scrambled) siRNA or not incubated with transfection reagents (nontransfected samples) and incubated for 24 hours. The cells were then incubated with either serum-free medium alone or serum-free medium containing $1 \mathrm{ng} / \mathrm{mL}$ of IL- $1 \beta$ for 72 hours. Cell proliferation was then measured using the Alamar Blue assay. The results are presented as means \pm SE and represent values from three experiments. Statistical analysis was performed using the one-way analysis of variance test $(P=0.016)$ followed by paired Student's $t$-test $\left({ }^{*} P=0.028\right.$, $\left.{ }^{*} P=0.041,{ }^{* * * P}=0.031\right)$, and statistical significance was taken as $P<0.05$. expression in fibroblasts 10 minutes and 1 hour after incubation with IL-1 $\beta$. Densitometric analysis of the bands confirmed significant changes at these times $(P=0.038$ at 10 minutes and $P=0.016$ at 1 hour) (Figure 14A). The importance of CD44 in mediating IL-1 $\beta$-driven ERK1/2 signaling was examined by knockdown of CD44 using siRNA. These results identified increased protein expression of ERK1/2 at 10 minutes and 1 hour compared with time 0 in untransfected
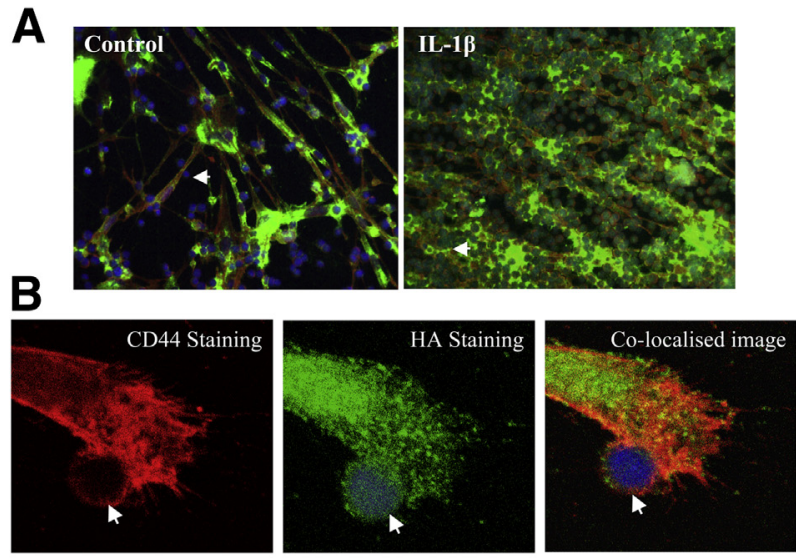

C
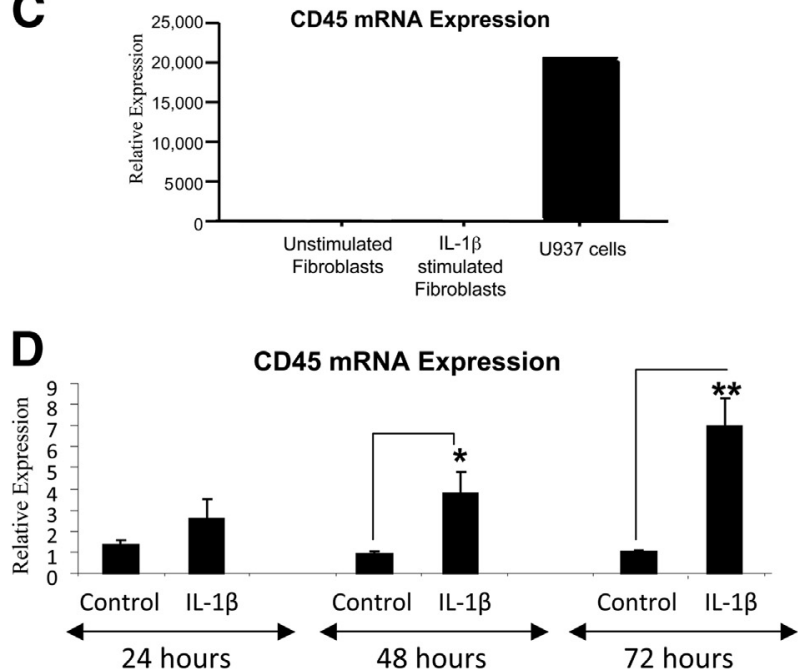

fibroblasts and fibroblasts transfected with negative control/ scrambled siRNA. However, fibroblasts transfected with CD44 siRNA had reduced phosphorylated ERK1/2 expression 1 hour after IL-1 $\beta$ stimulation (Figure 14B), thus indicating the importance of CD44 in mediating the IL- $1 \beta$-driven MAPK/ERK signaling in these cells. Similar assessments of MAPK/P38 signaling were also performed. However, although IL-1 $\beta$ stimulation demonstrated some increased P38

Figure 11 Effect of IL-1 $\beta$ on fibroblast-monocyte binding. $\mathbf{A}$ and $\mathbf{B}$ : Visualization of monocyte-fibroblast binding. Subconfluent monolayers of fibroblasts were growth arrested in serum-free medium for 48 hours. They were then incubated with either serum-free medium alone (control) or serum-free medium containing $1 \mathrm{ng} / \mathrm{mL}$ of IL-1 $\beta$ for 72 hours. U937 cells were simultaneously grown in RPMI medium. Subsequently, the conditioned medium from the stimulated fibroblasts was discarded and replaced with DMEM-F12 medium containing $1 \times 10^{6}$ monocytes per well. These two cells were co-cultured for 4 hours; the cultures were then washed 10 times with $1000 \mathrm{~mL}$ of PBS to remove any unbound U937 cells. Subsequently, the cells were fixed and stained with bHABP (green), CD44 (red), or DAPI (blue nuclear stain). The larger nuclei represent fibroblast nuclei, with the smaller nuclei representing the monocyte nuclei (arrowheads). B: Magnified image of the fibroblast-monocyte interaction in an IL-1 $\beta$-stimulated cell. C: Assessment of CD45 mRNA expression in fibroblasts. Confluent monolayers of lung fibroblasts were growth arrested in serum-free medium for 48 hours. The medium was then replaced with either serum-free medium alone (control) or serum-free medium containing $1 \mathrm{ng} / \mathrm{mL}$ of IL-1 $\beta$ and the incubations continued for 72 hours. CD45 mRNA expression was then assessed by RT-qPCR. As a positive control, $1 \times 10^{6} \mathrm{U} 937$ cells per well were cultured in 35-mm dishes and mRNA extracted for RT-qPCR for assessment of CD45 expression. D: Quantification of fibroblast-monocyte binding afater IL-1 $\beta$ stimulation by assessment of CD 45 mRNA expression. Confluent monolayers of fibroblasts were growth arrested in serum-free medium for 48 hours. They were then incubated with either serum-free medium alone (control) or serum-free medium containing $1 \mathrm{ng} / \mathrm{mL}$ of IL-1 $\beta$ for the indicated time points. U937 cells were simultaneously grown in RPMI medium. Subsequently, the conditioned medium from the stimulated fibroblasts was discarded and replaced with DMEM-F12 medium containing $1 \times 10^{6}$ monocytes per well. These two cells were co-cultured for 4 hours. The cultures were then washed 10 times with 1000 $\mu \mathrm{L}$ of PBS to remove any unbound U937 cells. The cells were subsequently lyzed with Tri-reagent and RNA extracted. RT-qPCR was used to assess CD45 mRNA expression. Because fibroblasts do not express CD45, increased CD45 expression was an indication of increased presence of monocytes. Statistical analysis was performed using the one-way analysis of variance test $(P=0.002)$, followed by paired Student's $t$-test $\left({ }^{*} P=0.03,{ }^{*} P=0.021\right)$, and statistical significance was taken as $P<0.05$. The experiment represents the mean of three samples for each experimental condition. Original magnification: $\times 6100$ (B). 


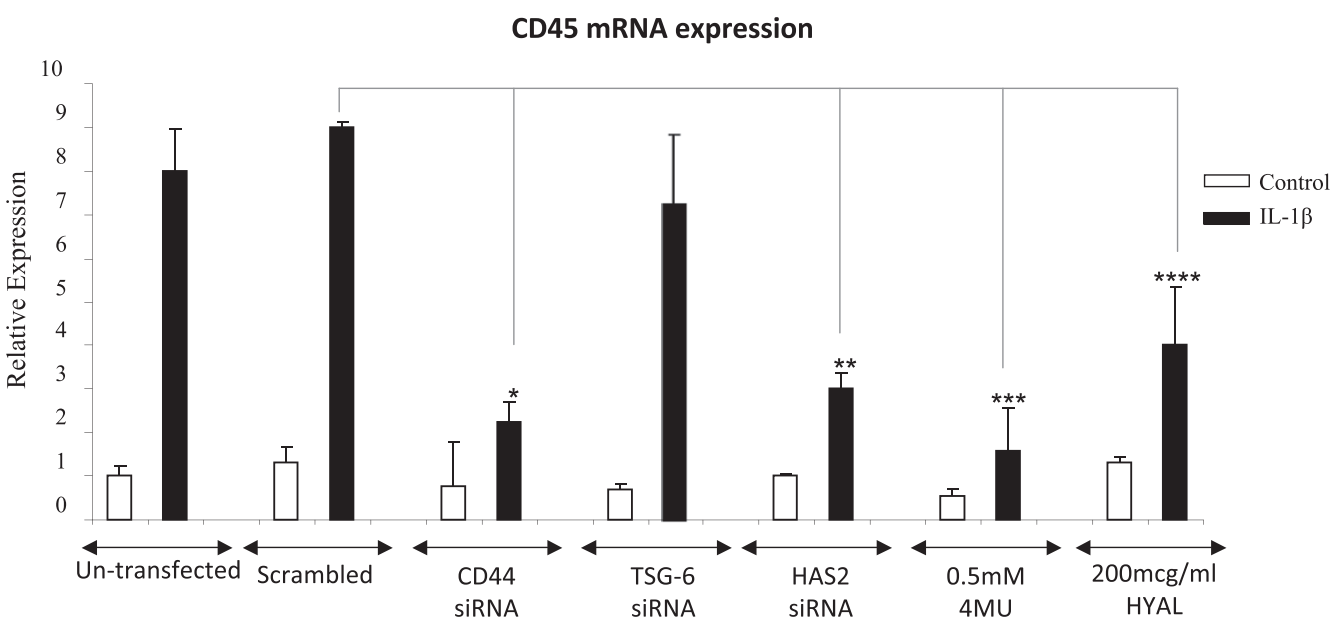

Figure 12 Assessment of the effect of 4MU, hyaluronidase, HAS2, CD44, and TSG siRNA on fibroblast-monocyte binding. Subconfluent monolayers of lung fibroblasts were growth arrested in serum-free medium for 48 hours. The cells were subsequently incubated with $0.5 \mathrm{mmol} / \mathrm{L} 4 \mathrm{MU}$, incubated with $200 \mu \mathrm{g} / \mathrm{mL}$ of bovine testicular hyaluronidase, or transfected with CD44, HAS2, or TSG-6 siRNA and the incubations continued for 24 hours. The fibroblasts were then incubated with either serum-free medium alone (control) or serum-free medium containing $1 \mathrm{ng} / \mathrm{mL}$ of IL-1 $\beta$ for 72 hours. As previously described, U937 cells were simultaneously grown in RPMI medium. Subsequently, the conditioned medium from the stimulated fibroblasts was discarded and replaced with DMEMF12 medium containing $1 \times 10^{6}$ monocytes per well. These two cells were co-cultured for 4 hours. The cultures were then washed 10 times with $1000 \mu \mathrm{L}$ of PBS to remove any unbound U937 cells. RT-qPCR was then used to assess CD45 mRNA. The experiment represents the mean of three samples for each experimental condition, and statistical analysis was performed using the one-way analysis of variance test $(P=0.0049)$, followed by paired Student's $t$-test $\left({ }^{*} P=0.038\right.$, $* * P=0.041,{ }^{* *} P=0.048$ and $\left.{ }^{* * *} P=0.0098\right)$.

signaling, these changes were not significant afrer densitometric analysis and were not found to be CD44 dependent (Supplemental Figure S1). Hence, P38 signaling is unlikely to be involved in IL-1 $\beta$-driven CD44-dependent fibroblastmonocyte binding. Involvement of ERK1/2 signaling in fibroblast-monocyte binding was subsequently assessed using the chemical ERK inhibitor PD98059. Initially, we again demonstrated a significant increase in CD45 mRNA expression in fibroblast-monocytes co-cultures after stimulation with IL-1 $\beta$. However, incubation with $10 \mu \mathrm{mol} / \mathrm{L}$ of the ERK inhibitor markedly attenuated this increase in CD45 mRNA expression, suggesting a reduction in fibroblast-monocyte binding (Figure 15).

\section{Discussion}

The fibroblast is the most abundant cell type in connective tissue and plays a central role in tissue remodeling and repair in both health and disease. Differentiation of fibroblasts to their active myofibroblast phenotype is largely regulated by the cytokine TGF- $\beta 1 .{ }^{16}$ Both the release of TGF- $\beta 1$ and its subsequent action in driving fibroblast differentiation is crucial for fibrosis to take place. Hence, much of our previous work has focused on the regulation of TGF- $\beta 1$ function and on the manipulation of fibroblast phenotype. We have previously characterized the TGF- $\beta 1$-dependent changes in extracellular matrix and intracellular signal transduction that are necessary for fibroblast phenotypic activation. ${ }^{49,51,52,61}$ Furthermore, we have outlined how TGF- $\beta 1$ induces increased levels of the matrix macromolecule HA and defined how the TGF- $\beta 1-$ dependent HA generation plays a functional role in regulating fibroblast phenotypic activation. ${ }^{49}$ We have also previously investigated the effect of the potent inflammatory cytokine IL-1 $\beta$ on HA generation in fibroblasts. We have data demonstrating that fibroblasts substantially increase HA generation after IL- $1 \beta$ stimulation. ${ }^{49}$ However, the HA generated in these circumstances was shown to have no link with fibroblast phenotypic activation, and its functional significance was not understood. We have outlined the differences in HA generation, distribution, and assembly afrer TGF- $\beta 1$ and IL- $1 \beta$ stimulation in fibroblasts and demonstrated a proinflammatory role for IL-1 $\beta$-induced HA in the regulation of fibroblast-monocyte binding.

Numerous cell types have been found to assemble HA matrices that surround individual cells. These matrices have previously been found to have a variety of functionally important roles, ranging from promotion of cell migration, proliferation, and differentiation to facilitation of tumor invasion, cancer progression, and promotion of multidrug resistance. ${ }^{44,62-65}$ The pericellular HA matrix is thought to be tethered to the cell membrane of cells either by HA bound to CD44 or by HA bound to the HAS enzymes as it is synthesized. In our studies, we have now established that both the TGF- $\beta 1-$ and the IL- $1 \beta$-dependent pericellular HA matrixes are dependent on synthesis of HA via the HAS2 enzyme. In addition, both the TGF- $\beta 1-$ and the IL- $1 \beta-$ dependent matrixes are also shown to be CD44 dependent. ${ }^{51,52}$ However, the matrices formed by these two cytokines are structurally very different. TGF- $\beta 1$ induces the formation of a compact HA coat that closely surrounds the cell membrane of fibroblasts, whereas IL- $1 \beta$ induces the formation of multiple spiculated membrane protrusions from 

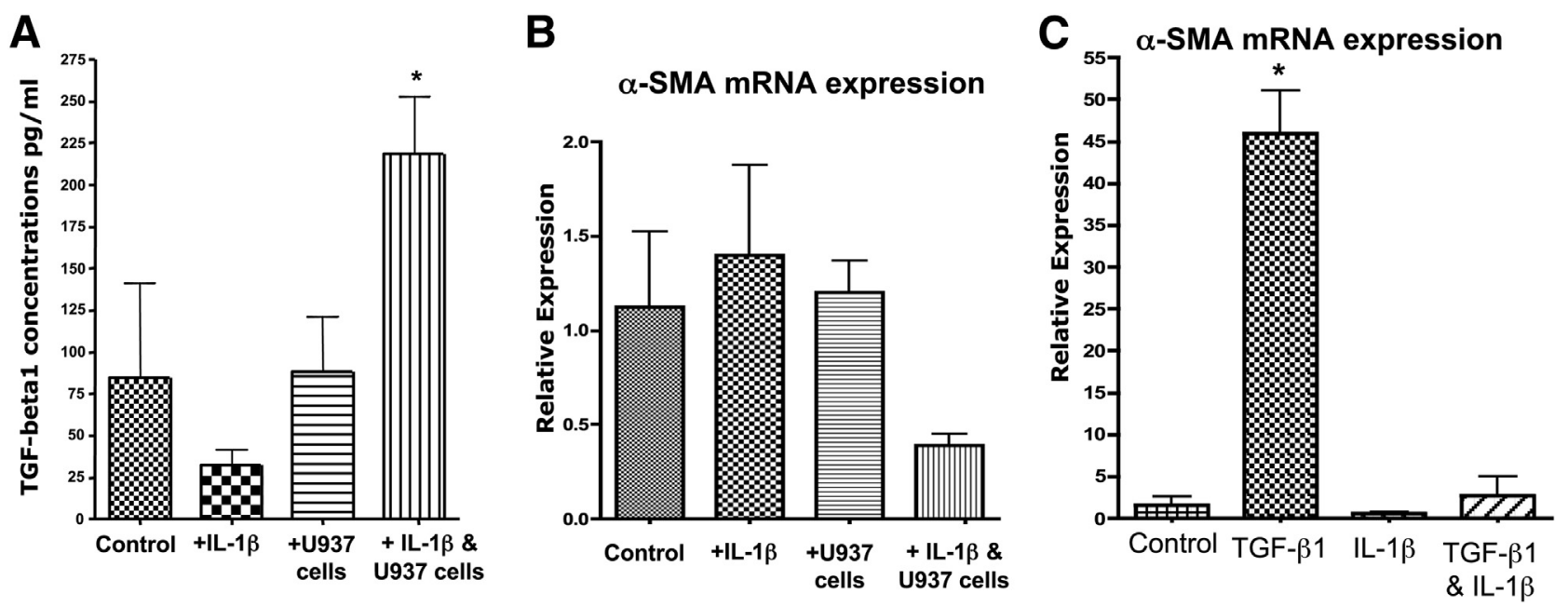

Figure 13 Effect of IL-1 $\beta$-driven fibroblast-monocyte binding on TGF- $\beta 1$ generation and myofibroblast formation. A: Assessment of TGF- $\beta 1$ generation in IL-1 $\beta$-driven fibroblast-monocyte co-cultures. Confluent monolayers of lung fibroblasts were growth arrested in serum-free medium for 48 hours. The medium was then replaced with either serum-free medium alone (control) or serum-free medium containing $1 \mathrm{ng} / \mathrm{mL}$ of IL-1 $\beta$ and the incubations continued for 72 hours. A subset of control wells and a subset IL-1 $\beta$-stimulated wells were incubated with U937 cells for 6 hours as described in Materials and Methods. The supernatant was subsequently removed and quantified for TGF- $\beta 1$ generation using ELISA. The experiment represents the mean of three samples for each experimental condition and statistical analysis was performed using paired Student's $t$-test with $P<0.05$ considered as significant. B: Assessment of $\alpha$-SMA mRNA expression in fibroblasts after IL-1 $\beta$ stimulation and incubation with monocytes. Confluent monolayers of lung fibroblasts were growth arrested in serum-free medium for 48 hours. The medium was then replaced with either serum-free medium alone (control) or serum-free medium containing $1 \mathrm{ng} / \mathrm{mL}$ of IL-1 $\beta$ and the incubations continued for 72 hours. A subset of control wells and a subset IL-1 $\beta$-stimulated wells were incubated with U937 cells for 6 hours as in A. Subsequently, the medium was removed and the cultures were washed with 10 times with $1000 \mu \mathrm{L}$ of PBS. $\alpha$-SMA mRNA expression was then assessed by RT-qPCR. The experiment represents the mean of three samples for each experimental condition, and statistical analysis was performed using paired Student's $t$-test with $P<0.05$ considered as significant. C: Assessment of $\alpha$-SMA mRNA expression in fibroblasts pretreated with IL-1 $\beta$ before stimulation with TGF- $\beta 1$. Confluent monolayers of lung fibroblasts were growth arrested in serum-free medium for 48 hours. The medium was then replaced with either serum-free medium alone (control) or serum-free medium containing $1 \mathrm{ng} / \mathrm{mL}$ of IL-1 $\beta$ and the incubations continued for 72 hours. A subset of control wells and a subset IL-1 $\beta$-stimulated wells were then subsequently incubated with $10 \mathrm{ng} / \mathrm{mL}$ of TGF- $\beta 1$ for 72 hours as shown in labels. $\alpha$-SMA mRNA expression was then assessed by RT-qPCR. The experiment represents the mean of three samples for each experimental condition, and statistical analysis was performed using paired Student's $t$-test, with $P<0.05$ considered as significant.

which the pericellular HA appears to protrude. It is now clear that after stimulation with TGF- $\beta 1$, HAS2, and TSG-6 expression are induced, and CD44 expression is attenuated in fibroblasts. TSG-6 influences organization and assembly of pericellular HA into compact HA coats, which then bind to and influence CD44 distribution within the cell membrane. In our previous work, we have demonstrated that this TGF- $\beta 1-$ dependent HA-CD44 interaction then promotes coupling of CD44 with the epidermal growth factor receptor with induction of intracellular ERK/MAPK signaling, leading to fibroblast differentiation.

TSG-6 is a secreted inflammation-associated protein composed of adjacent link module and CUB domains. ${ }^{66}$ It can bind to HA directly through its link domain. ${ }^{67}$ However, it can also stabilize HA matrices through covalent transfer of heavy chains of the inter- $\alpha$-inhibitor family of serum proteoglycans to HA-based structures. ${ }^{59,60}$ Thus, it has been reported to be essential for the organization of many pericellular HA-based structures. Our data indicate that TSG-6 is highly induced by both IL- $1 \beta$ and TGF- $\beta 1$. In TGF- $\beta 1-$ dependent HA matrices, TSG-6 is very clearly linked to the acquisition of a myofibroblast phenotype ${ }^{51}$, however, TSG-6 does not appear to be involved in maintenance of IL-1 $\beta-$ dependent HA matrices, and its increased mRNA and protein expression after IL-1 $\beta$ stimulation are not understood from this work. It is worth noting here that although the red cell exclusion assay demonstrates a significant HA pericellular coat present in TGF- $\beta 1$-stimulated fibroblasts, when we use HABP to demonstrate the presence of HA immunohistochemically, only a thin pericellular HA coat is demonstrated in our results. This is speculated to be because the HA coat in the TGF- $\beta 1-$ stimulated cells is already bound to TSG-6, thereby preventing the HA from binding to the exogenous HABP added during IHC staining.

IL-1 $\beta$ in fibroblasts induces HAS2, CD44, and ICAM-1 expression. Without TSG-6 incorporation, the increased HA generated after HAS2 induction does not form a compact HA coat but instead protrudes from the cell membrane in a linear manner. Other researchers have indicated that enhanced HAS enzyme expression can promote the formation of numerous membrane protrusions in a variety of cell types. ${ }^{68}$ Thus, in fibroblasts, the enhanced HAS2 expression and resultant HA generation after IL- $1 \beta$ stimulation, in the absence of TSG-6 incorporation, may also be responsible for the formation of membrane projections from which the pericellular HA protrudes. This manner of pericellular HA organization and resulting alterations in membrane structure may then be responsible for promoting redistribution of both 
A
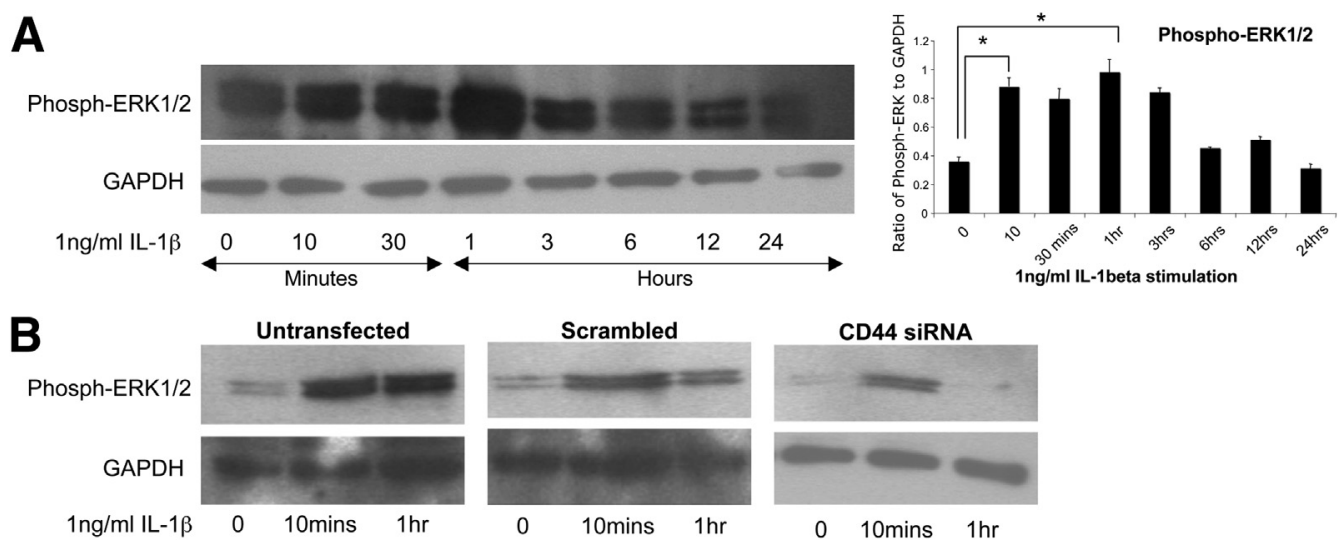

Figure 14 ERK signaling after IL-1 $\beta$ stimulation in lung fibroblasts. A: Assessment of ERK1/2 signaling after IL- $1 \beta$ stimulation in fibroblasts. Confluent monolayers of lung fibroblasts were growth arrested in serum-free medium for 48 hours. The cells were then stimulated with $1 \mathrm{ng} / \mathrm{mL}$ of IL- $1 \beta$ according to the times shown. Phosphorylated ERK1/2 protein expression was assessed by Western blot analysis. GAPDH was used as a loading control. Scanning densitometry was used to correct phosphorylated ERK1/2 expression against expression of GAPDH. Statistical analysis was performed using the paired Student's $t$-test, and statistical significance was taken as $P<0.05$. B: Effect of CD 44 knockdown on ERK1/2 signaling after IL- $1 \beta$ stimulations in fibroblasts. Subconfluent monolayers of fibroblasts were growth arrested in serum-free medium for 24 hours. Fibroblasts were then transfected with either negative control/scrambled siRNA or CD44 siRNA for 24 hours. The cells were then stimulated with $1 \mathrm{ng} / \mathrm{mL}$ of IL- $1 \beta$ for zero minutes, 10 minutes, or 1 hour as shown. Phosphorylated ERK1/2 expression was assessed by Western blot analysis and compared with ERK1/2 expression in untransfected fibroblasts. GAPDH was used as a loading control.

CD44 and ICAM-1 to be concentrated within the membrane protrusions, thereby enabling CD44/ICAM-1 rather than CD44/EGF-R interaction. Consequently, instead of activating pathways involved in cell differentiation, these structural differences in pericellular HA appear to result in fibroblast immune activation and function in facilitating fibroblast-monocyte binding. Hence, the IL-1 $\beta$-dependent pericellular HA matrix appears to be proinflammatory rather than directly profibrotic in nature.

Differential regulation, distribution, and localization of the HA receptor by IL- $1 \beta$ and TGF- $\beta 1$ are other key differences in the 2 types of HA matrices formed and are crucial in mediating the altered outcomes after stimulation with these cytokines. CD44 is known to play an important role in the initiation of intracellular signals after binding of HA and has been reported to play a role in initiating MAPK, Smad, rho kinase, and focal adhesion kinase signaling. ${ }^{69-72}$ The manner in which HA is presented to CD44 for binding is thought to be important in dictating which signaling pathways are activated. For example, exogenous HA binding to CD44 activates different signaling pathways from endogenous pericellular HA, and high- and low-molecular-weight HA has also been reported to activate different signaling cascades. ${ }^{50,73-77}$ Furthermore, previous research has indicated that distribution of CD44 within the lipid raft and nonraft portion of cell membranes can alter its subsequent activation of signaling cascades and can facilitate its interactions with other membrane components and receptors. ${ }^{78} \mathrm{We}$ found that $\mathrm{CD} 44$ in unstimulated fibroblasts occupies the same area in the cell membranes as the lipid raft marker CtxB, thus indicating its likely location within lipid raft microdomains in these cells. After IL- $1 \beta$ stimulation, less CD44 is associated with CtxB. Furthermore, depletion of cholesterol necessary for maintenance of the lipid raft microdomains does not influence protrusion formation or the association between CD44 and ICAM-1, thus suggesting that
CD44 and ICAM-1 within the protrusions are associated with nonlipid raft microdomains within the cell membranes.

The intracellular signaling pathways that are mediated by IL-1 $\beta$-driven CD44-dependent fibroblast functions have also been explored in this article. Previous research performed in fibroblasts has demonstrated that HA binding to ICAM, HA-CD44 binding, and ICAM-1-monocyte binding can all augment ICAM-1 expression through P38 MAPK signaling, thus highlighting a mechanism through which perpetual inflammation can be driven. ${ }^{55,79-81}$ However, in this work, we demonstrate that ERK1/2 signaling and not

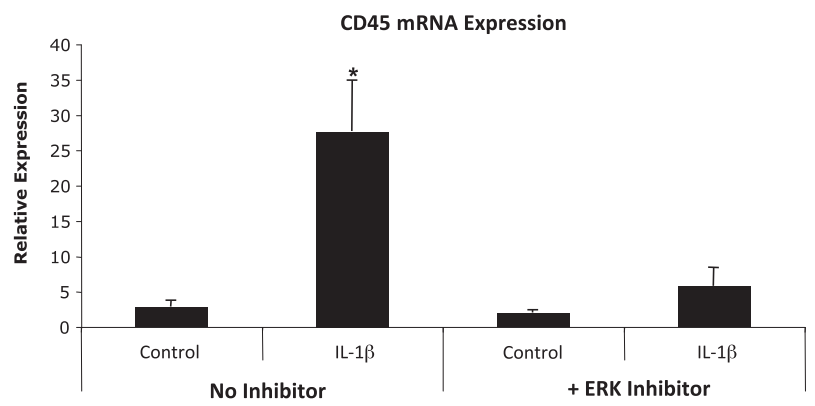

Figure 15 Effect of ERK inhibition in fibroblasts on IL-1 $\beta$-dependent fibroblast-monocyte binding. Confluent monolayers of lung fibroblasts were growth arrested in serum-free medium for 48 hours. The cells were subsequently incubated in serum-free medium alone or in serum-free medium containing $1 \mathrm{ng} / \mathrm{mL}$ of IL-1 $\beta$ in the presence or absence of $10 \mu \mathrm{mol} / \mathrm{L}$ of the ERK inhibitor PD98059 and the incubations continued for 72 hours. In parallel, U937 cells were simultaneously grown in RPMI medium. Subsequently, the conditioned medium from the stimulated fibroblasts was discarded and replaced with DMEM-F12 medium containing $1 \times 10^{6}$ monocytes per well. These two cells were co-cultured for 4 hours. The cultures were then washed 10 times with $1000 \mu \mathrm{L}$ of PBS to remove any unbound U937 cells. RT-qPCR was then used to assess CD 45 mRNA. The experiment represents the mean of three samples for each experimental condition, and statistical analysis was performed using the one-way analysis of variance test $(P=0.001)$ followed by paired Student's $t$-test $\left({ }^{*} P=0.03\right)$. 
P38 signaling is stimulated by IL- $1 \beta$ and mediated through CD44. This is surprising because the TGF- $\beta 1-$ driven fibroblast phenotype is also dependent on MAPK/ERK signaling. ${ }^{82}$ However, our previous work has demonstrated that ERK1/2 activation at 10 minutes is important for fibroblast to myofibroblast differentiation, whereas in the IL$1 \beta$-driven phenotype, CD44 appears to regulate ERK1/2 activation at the later time of 1 hour. Furthermore, it is clear that Smad activation is also important for the TGF$\beta 1-$ driven phenotype, and we have previously speculated that interaction between Smad and ERK pathways is necessary for TGF- $\beta 1$-dependent myofibroblast differentiation, whereas IL- $1 \beta$ does not influence the Smad pathway. ${ }^{83}$

Cells of the monocyte/macrophage lineage have been reported to be present in large numbers in both experimental models and human fibrotic diseases. ${ }^{84-86}$ Moreover, their presence has been reported to directly correlate with the severity of fibrosis and is found to be a good prognostic indicator of progressive fibrotic disease.$^{86}$ Our data provide a possible mechanism through which monocytes are sequestered by fibroblasts in the area of tissue injury, thus enabling propagation of the inflammatory response and promoting chronic inflammation and eventually fibrosis. Therefore, targeting of the HA/HAS2/CD44-dependent protrusions may provide a means of attenuating fibroblast-monocyte binding and ultimately regulating this process without counteracting all of the functions of IL-1 $\beta$, some of which may be beneficial to tissue repair. Our data also suggest that fibroblastmonocyte binding after IL-1 $\beta$ activation may in turn be responsible for increased levels of TGF- $\beta 1$ in tissues, thus ultimately influencing eventual fibrotic outcome. However, surprisingly, neither this increased production of endogenous TGF- $\beta 1$ nor addition of exogenous TGF- $\beta 1$ to fibroblasts initially activated by IL- $1 \beta$ led to increased myofibroblasts in the cultures. It is conceivable that in in vivo tissue environments, initial inflammation by mediators such as IL- $1 \beta$ leads to immune activation of a proportion of fibroblasts, leading to increased monocyte sequestration within tissues. However, although these cells themselves are resistant to myofibroblast differentiation, the resultant increased levels of TGF- $\beta 1$ in tissues acts on fibroblasts not activated by IL- $1 \beta$ and other myofibroblast precursors, such as epithelial cells and pericytes, leading to myofibroblast formation and increased extracellular matrix generation through processes such as epithelial-mesenchymal transition.

In summary, we describe that pericellular HA can be structured into yet another form. IL- $1 \beta$ stimulates fibroblasts to form numerous membrane protrusions and also stimulates increased ICAM-1, CD44, and HAS2 production. HAS2 enhances HA generation, which then protrudes from the membrane protrusions in a linear manner, leading to an increased pericellular HA matrix. ICAM-1 and CD44 become localized and interact within the protrusions. These changes in turn result in immune activation of fibroblasts by enhancing fibroblast-monocyte binding at the protrusions and leading to sequestration of monocytes within the inflamed tissue.

\section{Supplemental Data}

Supplemental material for this article can be found at http://dx.doi.org/10.1016/j.ajpath.2013.02.038.

\section{References}

1. Green FH: Overview of pulmonary fibrosis. Chest 2002, 122: 334S-339S

2. Chapman HA: Disorders of lung matrix remodeling. J Clin Invest 2004, 113:148-157

3. Eddy AA: Molecular insights into renal interstitial fibrosis. J Am Soc Nephrol 1996, 7:2495-2508

4. Bedossa P, Paradis V: Liver extracellular matrix in health and disease. J Pathol 2003, 200:504-515

5. Border WA, Noble NA: Transforming growth factor beta in tissue fibrosis. N Engl J Med 1994, 331:1286-1292

6. Border WA, Noble NA: Fibrosis linked to TGF-beta in yet another disease. J Clin Invest 1995, 96:655-656

7. Blobe GC, Schiemann WP, Lodish HF: Role of transforming growth factor beta in human disease. N Engl J Med 2000, 342: $1350-1358$

8. Gabbiani G: The myofibroblast in wound healing and fibroconnective tissue disease. J Pathol 2003, 200:500-503

9. Heymann F, Trautwein C, Tacke F: Monocytes and macrophages as cellular targets in liver fibrosis. Inflamm Allergy Drug Targets 2009 , 8:307-318

10. Wynn TA, Barron L: Macrophages: master regulators of inflammation and fibrosis. Semin Liver Dis 2010, 30:245-257

11. Vernon MA, Mylonas KJ, Hughes J: Macrophages and renal fibrosis. Semin Nephrol 2010, 30:302-317

12. Gabbiani G, Ryan GB, Majne G: Presence of modified fibroblasts in granulation tissue and their possible role in wound contraction. Experientia 1971, 27:549-550

13. Adamson IY, Letourneau HL, Bowden DH: Enhanced macrophagefibroblast interactions in the pulmonary interstitium increases fibrosis after silica injection to monocyte-depleted mice. Am J Pathol 1989, 134:411-418

14. Clark JG, Kostal KM, Marino BA: Bleomycin-induced pulmonary fibrosis in hamsters: an alveolar macrophage product increases fibroblast prostaglandin E2 and cyclic adenosine monophosphate and suppresses fibroblast proliferation and collagen production. J Clin Invest 1983, 72:2082-2091

15. Lemaire I, Beaudoin H, Masse S, Grondin C: Alveolar macrophage stimulation of lung fibroblast growth in asbestos-induced pulmonary fibrosis. Am J Pathol 1986, 122:205-211

16. Vaughan MB, Howard EW, Tomasek JJ: Transforming growth factor-beta1 promotes the morphological and functional differentiation of the myofibroblast. Exp Cell Res 2000, 257:180-189

17. Yoshioka K, Takemura T, Murakami K, Okada M, Hino S, Miyamoto H, Maki S: Transforming growth factor-beta protein and mRNA in glomeruli in normal and diseased human kidneys. Lab Invest 1993, 68:154-163

18. Nagy P, Schaff Z, Lapis K: Immunohistochemical detection of transforming growth factor-beta 1 in fibrotic liver diseases. Hepatology 1991, 14:269-273

19. Anscher MS, Peters WP, Reisenbichler H, Petros WP, Jirtle RL: Transforming growth factor beta as a predictor of liver and lung fibrosis after autologous bone marrow transplantation for advanced breast cancer. N Engl J Med 1993, 328:1592-1598

20. Kanangat S, Postlethwaite A, Hasty K, Kang A, Smeltzer M, Appling W, Schaberg D: Induction of multiple matrix metalloproteinases in human dermal and synovial fibroblasts by Staphylococcus aureus: implications in the pathogenesis of septic arthritis and other soft tissue infections. Arthritis Res Ther 2006, 8:R176 
21. Vesey DA, Cheung C, Cuttle L, Endre Z, Gobe G, Johnson DW: Interleukin-1beta stimulates human renal fibroblast proliferation and matrix protein production by means of a transforming growth factorbeta-dependent mechanism. J Lab Clin Med 2002, 140:342-350

22. Vesey DA, Cheung CW, Cuttle L, Endre ZA, Gobe G, Johnson DW: Interleukin-1beta induces human proximal tubule cell injury, alphasmooth muscle actin expression and fibronectin production. Kidney Int 2002, 62:31-40

23. Tesch G, Nikolic-Paterson DJ, Main IW, Lan HY, Atkins RC: The role of interleukin-1 in mesangial proliferation. Contrib Nephrol 1995, 111:144-148

24. Nikolic-Paterson DJ, Main IW, Tesch GH, Lan HY, Atkins RC: Interleukin-1 in renal fibrosis. Kidney Int Suppl 1996, 54:S88-S90

25. Raghow R, Postlethwaite AE, Keski-Oja J, Moses HL, Kang AH: Transforming growth factor-beta increases steady state levels of type I procollagen and fibronectin messenger RNAs posttranscriptionally in cultured human dermal fibroblasts. J Clin Invest 1987, 79:1285-1288

26. Postlethwaite AE, Raghow R, Stricklin GP, Poppleton H, Seyer JM, Kang AH: Modulation of fibroblast functions by interleukin 1: increased steady-state accumulation of type I procollagen messenger RNAs and stimulation of other functions but not chemotaxis by human recombinant interleukin 1 alpha and beta. J Cell Biol 1988, 106:311-318

27. Keski-Oja J, Raghow R, Sawdey M, Loskutoff DJ, Postlethwaite AE, Kang AH, Moses HL: Regulation of mRNAs for type-1 plasminogen activator inhibitor, fibronectin, and type I procollagen by transforming growth factor-beta: divergent responses in lung fibroblasts and carcinoma cells. J Biol Chem 1988, 263:3111-3115

28. Ballou LR, Chao CP, Holness MA, Barker SC, Raghow R: Interleukin-1-mediated PGE2 production and sphingomyelin metabolism. Evidence for the regulation of cyclooxygenase gene expression by sphingosine and ceramide. J Biol Chem 1992, 267:20044-20050

29. Tiggelman AM, Boers W, Linthorst C, Sala M, Chamuleau RA: Collagen synthesis by human liver (myo)fibroblasts in culture: evidence for a regulatory role of IL-1 beta. IL-4, TGF beta and IFN gamma. J Hepatol 1995, 23:307-317

30. Radeke HH, Meier B, Topley N, Floge J, Habermehl GG, Resch K: Interleukin 1-alpha and tumor necrosis factor-alpha induce oxygen radical production in mesangial cells. Kidney Int 1990, 37:767-775

31. Jiang B, Haverty M, Brecher P: N-acetyl-L-cysteine enhances interleukin-1beta-induced nitric oxide synthase expression. Hypertension 1999, 34:574-579

32. Phillips AO, Topley N, Steadman R, Morrisey K, Williams JD: Induction of TGF-beta 1 synthesis in D-glucose primed human proximal tubular cells by IL-1 beta and TNF alpha. Kidney Int 1996, 50:1546-1554

33. Luo DD, Fielding C, Phillips A, Fraser D: Interleukin-1 beta regulates proximal tubular cell transforming growth factor beta-1 signalling. Nephrol Dial Transplant 2009, 24:2655-2665

34. Kolb M, Margetts PJ, Anthony DC, Pitossi F, Gauldie J: Transient expression of IL-1beta induces acute lung injury and chronic repair leading to pulmonary fibrosis. J Clin Invest 2001, 107:1529-1536

35. Koda K, Niitsu Y, Bunya M, Ito N, Sasagawa Y, Owada M, Morita K, Kohgo Y, Urushizaki I: [Increased production of interleukin-1 by macrophage from the patients with chronic liver disease and its implication for liver fibrosis]. Nippon Shokakibyo Gakkai Zasshi 1985, 82:1527-1532

36. Gieling RG, Wallace K, Han YP: Interleukin-1 participates in the progression from liver injury to fibrosis. Am J Physiol Gastrointest Liver Physiol 2009, 296:G1324-G1331

37. Spicer AP, McDonald JA: Characterization and molecular evolution of a vertebrate hyaluronan synthase gene family. J Biol Chem 1998, 273:1923-1932

38. Meyer MF, Kreil G: Cells expressing the DG42 gene from early Xenopus embryos synthesize hyaluronan. Proc Natl Acad Sci U S A 1996, 93:4543-4547

39. Kosaki R, Watanabe K, Yamaguchi Y: Overproduction of hyaluronan by expression of the hyaluronan synthase Has2 enhances anchorageindependent growth and tumorigenicity. Cancer Res 1999, 59:1141-1145
40. Legg JW, Lewis CA, Parsons M, Ng T, Isacke CM: A novel PKCregulated mechanism controls CD44 ezrin association and directional cell motility. Nat Cell Biol 2002, 4:399-407

41. Itano N, Atsumi F, Sawai T, Yamada Y, Miyaishi O, Senga T, Hamaguchi M, Kimata K: Abnormal accumulation of hyaluronan matrix diminishes contact inhibition of cell growth and promotes cell migration. Proc Natl Acad Sci U S A 2002, 99:3609-3614

42. Ito T, Williams JD, Al-Assaf S, Phillips GO, Phillips AO: Hyaluronan and proximal tubular cell migration. Kidney Int 2004, 65:823-833

43. Camenisch TD, Schroeder JA, Bradley J, Klewer SE, McDonald JA: Heart-valve mesenchyme formation is dependent on hyaluronanaugmented activation of ErbB2-ErbB3 receptors. Nat Med 2002, 8: 850-855

44. Zoltan-Jones A, Huang L, Ghatak S, Toole BP: Elevated hyaluronan production induces mesenchymal and transformed properties in epithelial cells. J Biol Chem 2003, 278:45801-45810

45. Chen WY, Abatangelo G: Functions of hyaluronan in wound repair. Wound Repair Regen 1999, 7:79-89

46. Toole BP: Hyaluronan in morphogenesis. J Intern Med 1997, 242: 35-40

47. Stern R: Hyaluronan metabolism: a major paradox in cancer biology. Pathol Biol (Paris) 2005, 53:372-382

48. Toole BP, Wight TN, Tammi MI: Hyaluronan-cell interactions in cancer and vascular disease. J Biol Chem 2002, 277:4593-4596

49. Meran S, Thomas D, Stephens P, Martin J, Bowen T, Phillips A, Steadman R: Involvement of hyaluronan in regulation of fibroblast phenotype. J Biol Chem 2007, 282:25687-25697

50. Meran S, Thomas DW, Stephens P, Enoch S, Martin J, Steadman R, Phillips AO: Hyaluronan facilitates transforming growth factor-beta1mediated fibroblast proliferation. J Biol Chem 2008, 283:6530-6545

51. Simpson RM, Meran S, Thomas D, Stephens $P$, Bowen $T$, Steadman R, Phillips A: Age-related changes in pericellular hyaluronan organization leads to impaired dermal fibroblast to myofibroblast differentiation. Am J Pathol 2009, 175:1915-1928

52. Webber J, Meran S, Steadman R, Phillips A: Hyaluronan orchestrates transforming growth factor-beta1-dependent maintenance of myofibroblast phenotype. J Biol Chem 2009, 284:9083-9092

53. Selbi W, de la Motte C, Hascall V, Phillips A: BMP-7 modulates hyaluronan-mediated proximal tubular cell-monocyte interaction. J Am Soc Nephrol 2004, 15:1199-1211

54. Fujii K, Tanaka Y, Hubscher S, Saito K, Ota T, Eto S: Crosslinking of CD44 on rheumatoid synovial cells augment interleukin 6 production. Lab Invest 1999, 79:1439-1446

55. Oertli B, Beck-Schimmer B, Fan X, Wuthrich RP: Mechanisms of hyaluronan-induced up-regulation of ICAM- 1 and VCAM-1 expression by murine kidney tubular epithelial cells: hyaluronan triggers cell adhesion molecule expression through a mechanism involving activation of nuclear factor-kappa B and activating protein-1. J Immunol 1998, 161:3431-3437

56. Kakizaki I, Kojima K, Takagaki K, Endo M, Kannagi R, Ito M, Maruo Y, Sato H, Yasuda T, Mita S, Kimata K, Itano N: A novel mechanism for the inhibition of hyaluronan biosynthesis by 4 methylumbelliferone. J Biol Chem 2004, 279:33281-33289

57. Oh JY, Roddy GW, Choi H, Lee RH, Ylostalo JH, Rosa RH, Jr., Prockop DJ: Anti-inflammatory protein TSG-6 reduces inflammatory damage to the cornea following chemical and mechanical injury. Proc Natl Acad Sci U S A 107:16875-16880

58. Bardos T, Kamath RV, Mikecz K, Glant TT: Anti-inflammatory and chondroprotective effect of TSG-6 (tumor necrosis factor-alphastimulated gene-6) in murine models of experimental arthritis. Am J Pathol 2001, 159:1711-1721

59. Fulop C, Szanto S, Mukhopadhyay D, Bardos T, Kamath RV, Rugg MS, Day AJ, Salustri A, Hascall VC, Glant TT, Mikecz K: Impaired cumulus mucification and female sterility in tumor necrosis factor-induced protein-6 deficient mice. Development 2003, 130:2253-2261

60. Rugg MS, Willis AC, Mukhopadhyay D, Hascall VC, Fries E, Fulop C, Milner CM, Day AJ: Characterization of complexes formed 
between TSG-6 and inter-alpha-inhibitor that act as intermediates in the covalent transfer of heavy chains onto hyaluronan. J Biol Chem 2005, 280:25674-25686

61. Evans RA, Tian YC, Steadman R, Phillips AO: TGF-beta1-mediated fibroblast-myofibroblast terminal differentiation-the role of Smad proteins. Exp Cell Res 2003, 282:90-100

62. Evanko SP, Angello JC, Wight TN: Formation of hyaluronan- and versican-rich pericellular matrix is required for proliferation and migration of vascular smooth muscle cells. Arterioscler Thromb Vasc Biol 1999, 19:1004-1013

63. Knudson CB, Toole BP: Changes in the pericellular matrix during differentiation of limb bud mesoderm. Dev Biol 1985, 112:308-318

64. Knudson CB, Munaim SI, Toole BP: Ectodermal stimulation of the production of hyaluronan-dependent pericellular matrix by embryonic limb mesodermal cells. Dev Dyn 1995, 204:186-191

65. Knudson CB, Knudson W: Similar epithelial-stromal interactions in the regulation of hyaluronate production during limb morphogenesis and tumor invasion. Cancer Lett 1990, 52:113-122

66. Blundell CD, Almond A, Mahoney DJ, DeAngelis PL, Campbell ID, Day AJ: Towards a structure for a TSG-6.hyaluronan complex by modeling and NMR spectroscopy: insights into other members of the link module superfamily. J Biol Chem 2005, 280: 18189-18201

67. Blundell CD, Mahoney DJ, Almond A, DeAngelis PL, Kahmann JD, Teriete P, Pickford AR, Campbell ID, Day AJ: The link module from ovulation- and inflammation-associated protein TSG-6 changes conformation on hyaluronan binding. J Biol Chem 2003, 278: 49261-49270

68. Kultti A, Rilla K, Tiihonen R, Spicer AP, Tammi RH, Tammi MI: Hyaluronan synthesis induces microvillus-like cell surface protrusions. J Biol Chem 2006, 281:15821-15828

69. Bourguignon LY, Singleton PA, Zhu H, Diedrich F: Hyaluronanmediated CD44 interaction with RhoGEF and Rho kinase promotes Grb2-associated binder-1 phosphorylation and phosphatidylinositol 3-kinase signaling leading to cytokine (macrophage-colony stimulating factor) production and breast tumor progression. J Biol Chem 2003, 278:29420-29434

70. Bourguignon LY, Zhu H, Shao L, Chen YW: CD44 interaction with c-Src kinase promotes cortactin-mediated cytoskeleton function and hyaluronic acid-dependent ovarian tumor cell migration. J Biol Chem 2001, 276:7327-7336

71. Bourguignon LY, Zhu D, Zhu H: CD44 isoform-cytoskeleton interaction in oncogenic signaling and tumor progression. Front Biosci 1998, 3:d637-d649

72. Ponta H, Sherman L, Herrlich PA: CD44: from adhesion molecules to signalling regulators. Nat Rev Mol Cell Biol 2003, 4:33-45
73. Ito T, Williams JD, Fraser D, Phillips AO: Hyaluronan attenuates transforming growth factor-beta1-mediated signaling in renal proximal tubular epithelial cells. Am J Pathol 2004, 164:1979-1988

74. Webber J, Jenkins RH, Meran S, Phillips A, Steadman R: Modulation of TGFbeta1-dependent myofibroblast differentiation by hyaluronan. Am J Pathol 2009, 175:148-160

75. Termeer CC, Hennies J, Voith U, Ahrens T, Weiss JM, Prehm P, Simon JC: Oligosaccharides of hyaluronan are potent activators of dendritic cells. J Immunol 2000, 165:1863-1870

76. Taylor KR, Trowbridge JM, Rudisill JA, Termeer CC, Simon JC, Gallo RL: Hyaluronan fragments stimulate endothelial recognition of injury through TLR4. J Biol Chem 2004, 279:17079-17084

77. Xu H, Ito T, Tawada A, Maeda H, Yamanokuchi $\mathrm{H}$, Isahara $\mathrm{K}$, Yoshida K, Uchiyama Y, Asari A: Effect of hyaluronan oligosaccharides on the expression of heat shock protein 72 . J Biol Chem 2002, 277:17308-17314

78. Lee JL, Wang MJ, Sudhir PR, Chen JY: CD44 engagement promotes matrix-derived survival through the CD44-SRC-integrin axis in lipid rafts. Mol Cell Biol 2008, 28:5710-5723

79. Clayton A, Evans RA, Pettit E, Hallett M, Williams JD, Steadman R: Cellular activation through the ligation of intercellular adhesion molecule-1. J Cell Sci 1998, 111(pt 4):443-453

80. Fujii Y, Fujii K, Nakano K, Tanaka Y: Crosslinking of CD44 on human osteoblastic cells upregulates ICAM-1 and VCAM-1. FEBS Lett 2003, 539:45-50

81. Bourguignon LY, Singleton PA, Zhu H, Zhou B: Hyaluronan promotes signaling interaction between CD44 and the transforming growth factor beta receptor I in metastatic breast tumor cells. J Biol Chem 2002, 277:39703-39712

82. Simpson RM, Wells A, Thomas D, Stephens P, Steadman R, Phillips A: Aging fibroblasts resist phenotypic maturation because of impaired hyaluronan-dependent CD44/epidermal growth factor receptor signaling, Am J Pathol 176:1215-1228

83. Meran S, Luo DD, Simpson R, Martin J, Wells A, Steadman R, Phillips AO: Hyaluronan facilitates transforming growth factor-beta1dependent proliferation via CD44 and epidermal growth factor receptor interaction. J Biol Chem 286:17618-17630

84. Lan HY, Paterson DJ, Atkins RC: Initiation and evolution of interstitial leukocytic infiltration in experimental glomerulonephritis. Kidney Int 1991, 40:425-433

85. Bohle A, Wehrmann M, Bogenschutz O, Batz C, Vogl W, Schmitt H, Muller CA, Muller GA: The long-term prognosis of the primary glomerulonephritides: a morphological and clinical analysis of 1747 cases. Pathol Res Pract 1992, 188:908-924

86. Eddy AA: Interstitial macrophages as mediators of renal fibrosis. Exp Nephrol 1995, 3:76-79 